\title{
RELATIVE ABSORPTION OF SOME NUTRIENT ELEMENTS BY THE TOMATO PLANT AS AFFECTED BY THE STAGE OF GROWTH
}

By

EDUARDO JIMENEZ S.

A Thesis Presented to the Graduate Council of THE UNIVERSITY OF FLORIDA

in Partial Fulfilment of the Requirements for the

Degree of Master of Science in Agriculture

UNIVERSITY OF FLORIDA

JUNE, 1955 


\section{ACKNOWLEDGEMENT}

The author wishes to express his deepest appreciation to Dr. C. B. Hall for the wise direction and supervision of this investigation; to Dr. T. W. Stearns and Dr. G. J. Stout, the other members of the Committee, for their valuable suggestions and reading of the manuscript; to Dr. D. B. Duncan, professor of Statistics, for his contribution made through the numerous advices in the use of the statistical methods; to Mr. R. D. Roush, technician of the Vegetable Products Laboratory, and to all those members of the Florida Agricultural Experiment Station at Gainesville, who in some way or another contributed to make possible the accomplishnent of this work.

The author sincerely wishes to express his indebtedness to Dr. R. A. Dennison, Interim Head of the Horticulture Department of the Florida Experiment Station, Gainesville, and Dr. W. Popenoe, Director of the Panamerican School of Agriculture, Honduras, for their part in obtaining the required economical support. 
INTRODUCTION.......................... I

REVIEW OF LITERATURE.................... 3



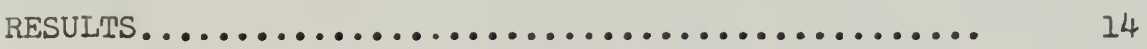

Total Absorption................... 14

Percentage of Dry Matter............... 16

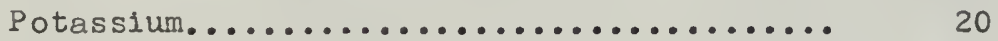

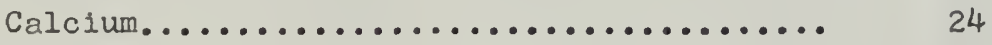

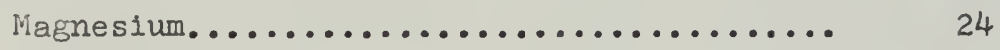

Phosphorus....................... 31

Nitrogen................................. 31

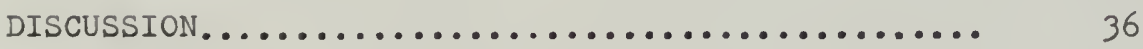

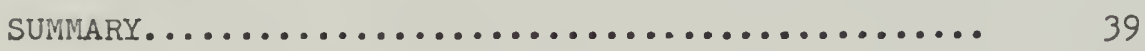

APPENDIX................................ 41

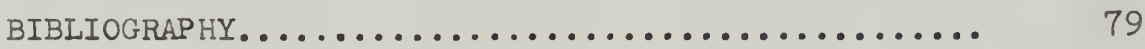




\section{INTKODUCTION}

A large amount of research work has been done in the field of plant nutrition since 1804, when de Saussure estabIished that the plant depends upon the soll for the supply of nitrogen and the mineral components of the ash. A better knowledge about the nutrient elements was gained after Liebig's work, published in 1840, which demonstrated that the soil furnishes the growing plant with the elements calcium, potassium, sulfur, and phosphorus. But the great advances in the field of mineral nutrition came after the Introduction by Sachs and Knop, in 1860, of the methods of Iiquid culture which have been ever since the basis of this type of experimentation (1).

A marked tendency toward the study of the rate of absorption of nutrient elements by different plants began late in the nineteenth century. The idea has always been to gather sound information that can be applied practically in the attempt to make crop production a more successful enterprise, both from the economic and scientific points of view.

Several factors have induced the undertaking of the present investigation: the need for more detailed 
information concerning the relative absorption of some of the nutrient elements by the tomato plant at different stages of development; a complete recognition of the various factors that affect the nutrient absorption by different specles of plants; and finally, the fact that most of the studies performed up to date have not considered the mineral absorption in terms of the amounts taken up by the plent per unit produced of fresh and dry weights respectively. It is, therefore, the purpose of this work to present data concerned primarily with the relative absorption of some nutrient elements by the tomato plant at five stages of growth. Emphasis is placed on the cations calcium, potassium, and magnesium. Other elements also included in this study were phosphorus and nitrogen. 


\section{KEVIEW OF IIIERATUKE}

The earliest work published in the line of mineral uptake by plants of economic importance has been ascribed to Hernberg, 1822, who worked with corn. He was able to note that abrupt changes take place in the rate of absorption of various elements at definite stages of the development of corn plants. Hernberg reported that when the tassels were beginning to form there was a marked reduction in the rate of absorption followed by a period of rapid uptake which was then succeeded by the ripening period. At this point he noted that there was some loss of practically all nutrients due perhaps to outward diffusion of solutes and to the loss of leaves and roots (2). It should be mentioned here that the concept of outward movenent of nutrients from the plant to the external medium has been also sustained by other workers such as Hoagland (2) and Burd (3). More recently MacGillivray (4) could not detect any loss of phosphorus from tomato plants to the surrounding medium which was much lower in phosphoms concentration, and Arnon (5) has proved that there is a redistribution of this element in the tomato plant. Steward (6) says that apparentiy the release of elements to the external solution occurs only in extreme 
cases. Hoagland ( 7 ) has stated in more recent publications that normally metabolizing cells are highly impermeable to salts, and that the electrostatic balance between the root and the solution is maintained externally by the release of bicarbonate, or hydrogen lons or perhaps others and internally by readjustment of the organic acid content.

Burd (3), studying the rate of absorption of soll nutrients by barley plants, found that a slight loss of calclum, potassium and nitrogen appears to take place when the heads are beginning to form, and he further concluded that the forces acting upon the mentioned elements may also affect others.

Hester, Shelton and Issacs (8) studied the rate and the amount of plant nutrients taken up by various vegetables -from the horticultural point of view. The data for tomato indicate that this plant begins to absorb nutrients in considerable amounts following the fourth week after transplanting. The largest absorption is during the latter part of the growing season when the fruit is forming. It is also ind icated that the amounts present in the top portion of the plant (expressed in pounds per acre of the crop), followed constantly up to the twelfth week this sequence: $\mathrm{K}_{2} \mathrm{O}>\mathrm{N}>\mathrm{Ca}>\mathrm{P}_{2} \mathrm{O}_{5}>\mathrm{Mg}$. The summarized form in which these authors present their data makes its applicability of limited value.

Collander (9) studied the selective absorption of 
several plant species without considering their stage of development. He grew the plants in different nutrient solutions of known composition, after which the cation composition of the plants was determined. Among his conclusions there is one of particular interest. That is that "single plant species are constantly, irrespective of the year of cultivation and composition of the culture solutions, found to be relatively rich in certain cations and other species as constantly relatively rich in other cations."

McCall and Richards (10) investigated the salt requirements of wheat plants at three different stages of growth. These workers considered the absorption of the salts as such, and this may lead to the conclusion that they overlooked the fact that the constituent ions of a salt are not necessarily absorbed in equivalent amounts which means that any attempt made to correlate the salt uptake with the growth made by those plants feeding upon such salt solutions has no sound basis. It is impossible, therefore, to separate from this sort of data the effect of the lons involved, or the amounts of them absorbed.

Shive and Martin (11) have reported that buckwheat plants produced their maximum yield of tops and roots during the latter stage of development (from the fourth to the eighth week) in a medium having a lower osmotic proportion of potassium phosphate, a much higher proportion of calcium nitrate, and a much lower one of magnesium sulfate than had 
the medium which produced the highest yield during the early growth perlod (from germination to the fourth week). Again, this work tells nothing about the relative amounts of lons absorbed by the plant from the two solutions used at the two stages of growth.

Jones and Huston (12) working with maize found that a very rapid absorption of potassium occurred four weeks after germination. This was followed by a period of relatively slow absorption which in turn was succeeded by another perlod of high uptake at the time the grains were developing. They also observed that the uptake of phosphorus did not undergo any appreciable varlation throughout the Iife cycle. It may be noted in their data that an increase in the amount of phosphorus absorbed on a dry weight basis occurs, as compared to the relative uptake of potassium and nitrogen after the blooming stage.

Pember (13), and Pember and McLean (14) observed that barley, oats, and wheat were able to make a more effective use of a limited amount of potassium if tne element was supplied early in their growth period. The time of the application of phosphorus made little difference, but small amounts of nitrogen were most beneficlal if supplied gradually over the entire growth period.

Gerlcke's work (15) with wheat agrees with the findings of the investigators just mentioned in respect to nitrogen and potassium, but differs somewhat in regard to 
the conclusions reached for phosphorus. Gericke says that a good supply of nitrogen is essential throughout the growth period of wheat, and the proper supply of potassium, magnesium, sulfur and phosphorus appearsto be required by this plant during the first four-week period of growth.

Brenchley (16), using barley, found results similar to those obtained by Gericke in relation to the absorption of phosphorus at early stages of growth. He found that barley plants grew normally and produced a good yield of grain if supplied with phosphorus during the first six weeks or longer. If the phosphorus was withheld for the first four weeks and then restored to the solution, the "tiller" production was not affected but no heads were produced. Brenchley also noted that the amount of phosphorus absorbed by the plant increased steadily in more or less direct proportion to the length of time the element was given at the beginning of growth; then, the uptake ceased during the latter stages of ripening of the grain.

Gile and Carrero (17) worked with rice and found a decrease in the percentage of potassium, phosphorus, and sulfur in the ash, and of nitrogen in the dry matter as the plant matured. They also observed that the percentage dry matter in the green plant did not rise until the plant had begun to form seeds.

"According to Chizhov (1926) all the necessary ash and nitrogenous compounds are accumulated by winter and 
spring crops about the period of blooming or grain forming. In the sunflower this accumulation is complete at about the same time of ripening, while in beans and potatoes it is completed at the end of the vegetative growth" (2). In the particular case of the tomato plant it may be expected that such accumulation of nutrients will not stop until the plant reaches senility. MacGillivray (4) considers the type of growth of the tomato plant as being of an intermediate type, Where the vegetative growth is concurrent with the development of fruits at all stages.

Bartholomew and Janssen (18) included tomato plants among several other species in their experiment. They found a high initial level of concentration of potassium in the plants during the early stages of growth. The height of this level was in proportion to the amount of potassium available to the plant. Nevertheless, they found that as the amount of growth increased, there was a very decided decrease in the potassium content of the plant. The authors considered that the supply of this element was short and thus concluded "that the glants, had taken up more potassium than was actually needed to perform normal ilfe processes and had reutilized this potassium when the incoming supply became insufficient for its normal growth."

Overstreet, Jacobson and Handley (19) studied the effect of calcium on the absorption of potassium by barley roots. They noted that the uptake of potassium was 
considerably greater than the uptake of calcium, and as the potassium concentration increased in the solution there was a reauction in the absorption of calcium. The authors also mentioned a reciprocal effect, in which case the absorption of potassium was markedly stimulated by the presence of calcium. Even relatively small concentrations of calcium exerted a stimulating effect which increased as the calcium concentration increased. For a given calcium concentration the effect diminished as the potassium concentration increased. As the potassium concentration decreased, calcium had an increasingly stimulating effect down to a concentration of $2 \times 10^{-4} \mathrm{~N} \mathrm{KCl}$. Below this value the stimulating effect diminished and eventually the calcium depressed the absorption of potassium at very low concentrations of potassium chloride.

Fisher (20), working with tomato, observed that plants which had been grown for four weeks (from the cotyledonary stage) in complete solutions before they were supplied with calcium deficient solutions, took three to five days to exhibit the symptoms denoting the lack of this element. 


\section{METHODS}

A strain of the Rutgers variety of tomato was planted in flats fllled with sterilized soil; the flats were watered regularly with tap water. When the seedlings passed the cotyledonary stage they were washed of the so1l and transferred to solutions in two-gallon glazed crocks, the inside of which had been coated with asphalt paint. The plants were pruned to one stem. As the plants reached the desired stage of maturity, five uniform plants were selected and transferred to similar crocks in a room in which the light, temperature, and humidity were controlled. Due to equipment Iimitations only one stage of growth could be run at a time.

The room used was an insulated storage room in which the relative humidity was maintained at about 30 percent. The temperature was about 75 degrees $F$ during the 1llum1nated period, and 70 degrees during the dark period. The light was supplied by three sets of 12 slimline fluorescent tubes 8 feet in length. One set was suspended at a helght of one and one-half feet above the top of the plants. The other two sets were suspended to the front and to the rear of the plants about one foot from the outer leaves. Three 
100-watt mazda lamps were placed just under the upper set of fluorescent tubes in order to increase the amount of red light. The intensity of light at the plant surface was about 800 foot candles as measured by a Weston light meter. The illuminated perioa was 12 hours dally.

The crocks in the room were numbered from 1 to 5 , so that the plant growing in each one of them could serve as a replicate in the experiment. Each crock contained 8 liters of solution of the composition suggested by Hoagland (No. 2), as given in the Appendix, with the exception that the concentration of ammonium phosphate was increased 50 percent over that recommended by the author.

The solutions were continually aerated by means of diffusion stones attached to a compressed air line. The volume of the solution was kept constant by the addition of distilled water; the nutrient contents of the solutions were very much the same in all the crocks. Wooden covers were used for the crocks and in order to maintain the plants in a vertical position they were fastened to stakes.

The plants were in the room for 3 days before beginning the studies. Three samples were drawn from the solution of each crock during every treatment (stage of growth). The first sample was taken just after the adition of fresh solution; the second, at the end of the third day; and the last one, at the end of the seventh day when the period of observation was over. The results of the analysis of the 
second sample were discarded. The elements whose absorption was measured were potassium, calcium, magnesium, phosphorus and nitrogen. The techniques used for their determinations were the quantitative spectral analysis for calcium and potassium, and colorimetric methods for phosphorus and magnesium. A Beckman Model B Spectrophotometer was used for this purpose. The nitrogen was determined as total nitrogen according to the Micro-Kjeldahl-Gunning method. The methods are given in the Appendix.

The absorption of the various elements made by each plant-replicate was obtained from the difference between the concentration of the 8 liters of solution at the beginning and the end of the seven-day period of observation as given in the Appendix.

At the end of each treatment, the plants were removed from the culture solutions and divided into leaves, stems, roots, and fruits for the determination of the fresh we1ght. Whenever flowers were present they were included in the same group with the leaves. The material was dried in a forced draft oven at 70 degrees $F$ for a week; then, the dry weight of each plant portion was determined.

The design of the present experiment is that of a randomized block type with five treatments (stages of growth) and five replications. The variable to be analyzed is the logarithm of a number representing the milligrams of the element absorbed per unit of fresh, or dry weight of the 
whole plant. The use of logarithms was dictated by the nature of the data; further explanation for their use is given in the Appendix.

The stages of growth which served as a basis of study in the present investigation were arbitrarily chosen. For a better understanding of what is meant by the different stages of growth, the following descriptions are given:

1. Seedling stage. The plants were about six inches high from the base of the stem to the top, and suitable for transplanting.

2. Stem Elongation stage. The plants were making rapid growth and still did not show any flower buds.

3. Flowering stage. The plants showed clusters of flowers.

4. Fruit Setting stage. The plants had fruits of less than one inch in diameter.

5. Fruit Enlargement stage. The plants had fruits of any size above one inch in diameter, but no one of which reached the mature green stage of development. 


\section{RESULTS}

Although fresh and dry welghts were determined for the various parts of the sampled plants, as given in the Appendix, only the data for the rate of absorption per unit of fresh, or dry welghts of the whole plant that were analyzed statistically will be discussed. In addition to the unit rates of absorption, the results of total absorption of the elements (Table 1) and the average percentage of dry matter at varlous stages of growth (Table 2) are presented.

\section{Total Absorption}

The total absorption of potassium, calcium, magnes1um, phosphorus, and nitrogen (Table 1) was found to increase almost constantly with maturity of the plant, as has been noted by other workers $(2,5,8,12,13,14,15,16)$. Except for nitrogen and magnesium, the uptake of nutrients is markedly accelerated as the plant approaches its reproductive period, and continues increasing unt1l the fruits are set. Once this point is reached, the absorption of potassium decreases considerably while the reduction in the uptake of phosphorus and magneslum is not so pronounced. Only nitrogen and calcium are still absorbed in larger amounts at the fruit enlargement stage. A complete plcture of the 


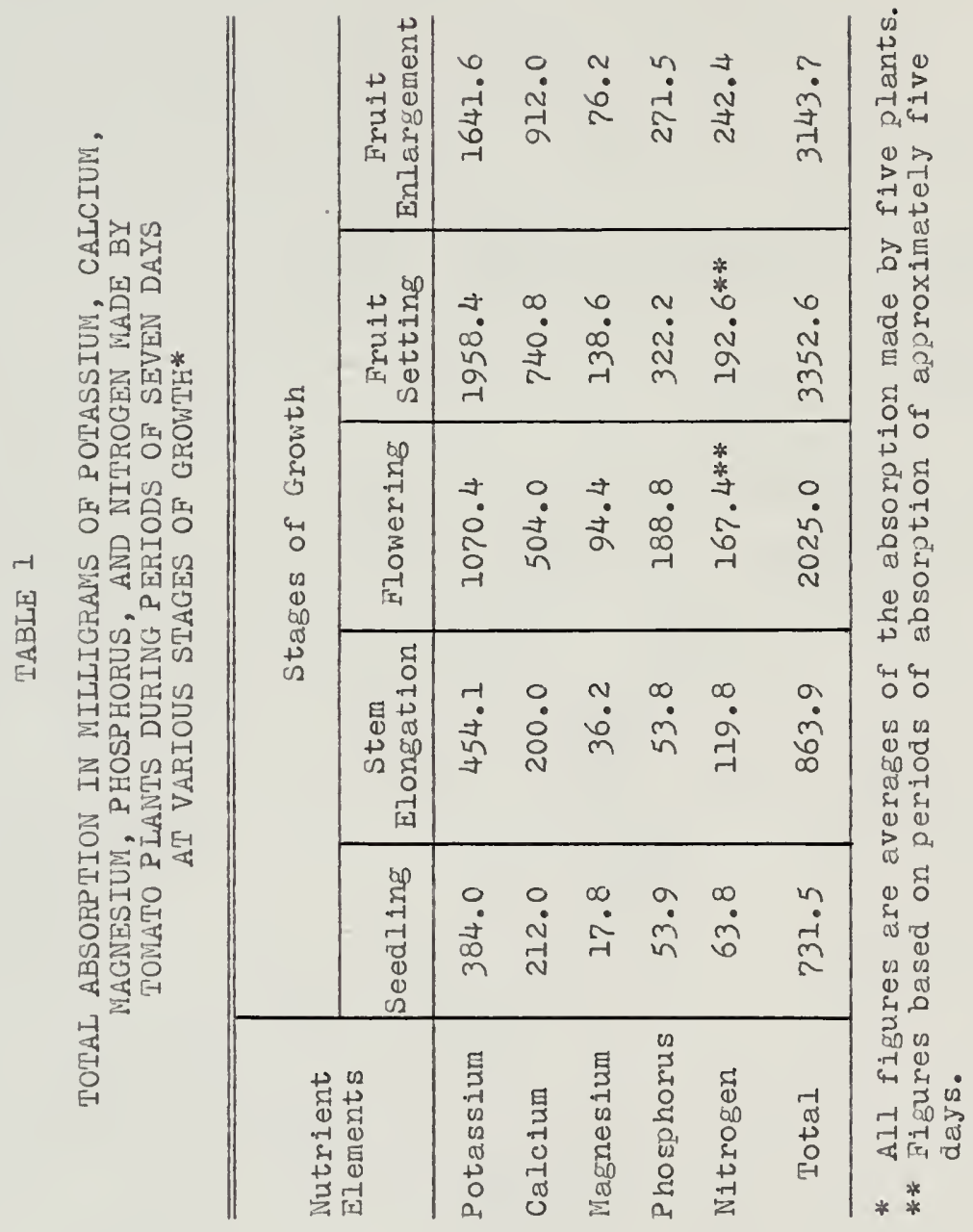


total absorption of these elements is given in Figure 1 . In general, it may be sald that during the vegetative stages of development the absorption of $\mathrm{K}>\mathrm{Ca}>\mathrm{N}>\mathrm{P}>\mathrm{Mg}$, while after the flowering stage, phosphorus is absorbed in larger amounts than nitrogen resulting in this other relationship: $\mathrm{K}>\mathrm{Ca}>\mathrm{P}>\mathrm{N}>\mathrm{Mg}$. Throughout the life cycle of the tomato plant, potassium and calcium are absorbed in the largest proportions, and magnesium is absorbed the least. The period of highest total absorption corresponds to the fruit setting stage, when there is a large proportion of actively metabolyzing cells in the plant. This last observation agrees with the results reported by Hester et al (8).

\section{Percentage of Dry Matter}

In regard to the percentage distribution of the dry matter of the tomato plant it may be observed (Table 2 and Figure 2) that the increase in percentage takes place very slowly during the periods of more active growth, namely, before the plant blooms, and then, when the fruits are developing. The explanation for this lag in the accumulation of dry material may be that during those periods of active growth there is a more rapid increase of fresh weight due to the formation of new vegetative tissue and expansion of the young fruits which results in small gains in percentage of dry weight. Considering that the enlargement of the tomato fruits occurs without any further addition of dry 
Figure 1. Total absorption, in milligrams, of potassium, calcium, magnesium, phosphorus, and nitrogen made by tomato plants during periods of seven days at the following stages of growth: (1) Seedling; (2) Stem elongation; (3) Flowering; (4) Fruit setting; (5) Fruit enlargement. (The ooints on the curves represent the average absorption of five plants.) 


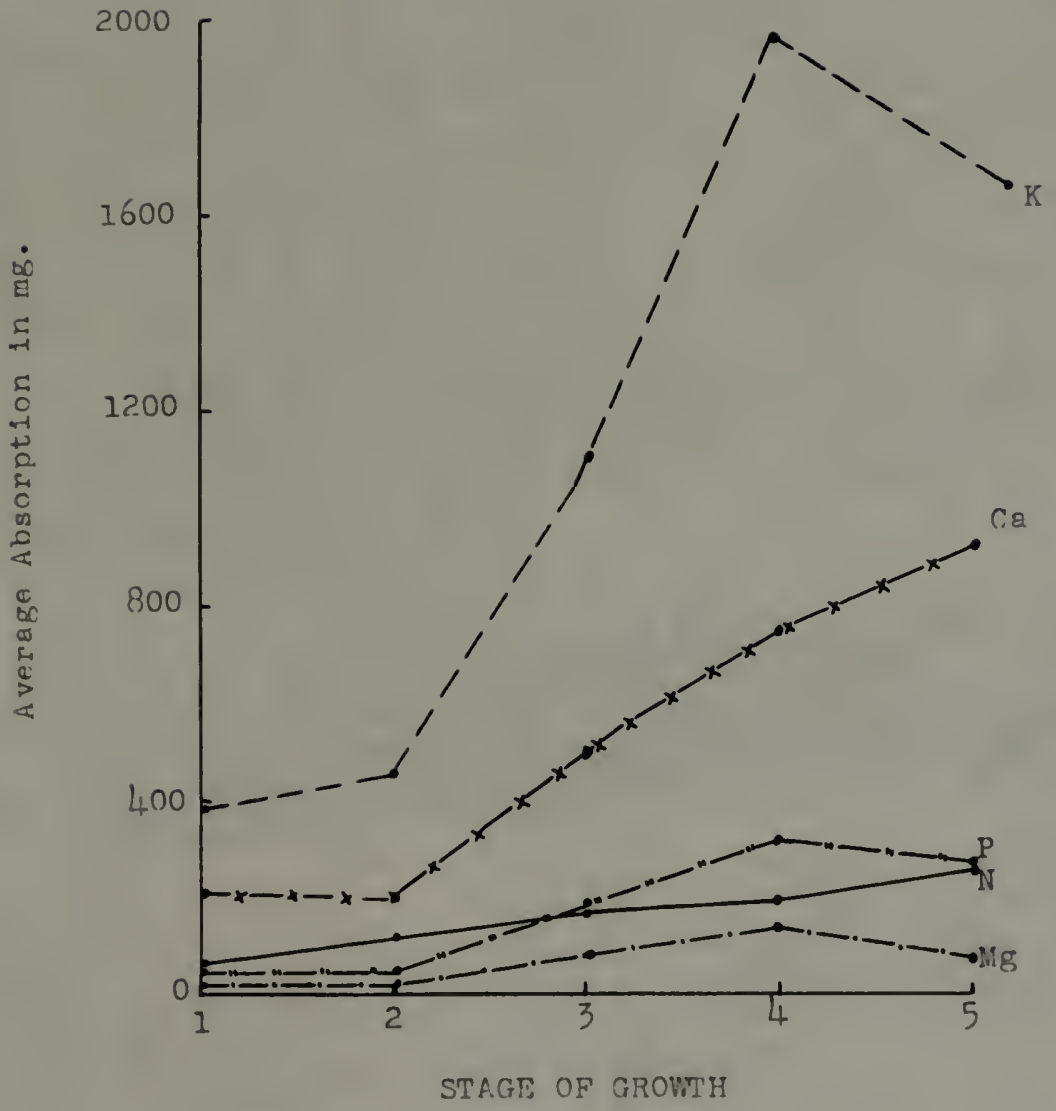


TABLE 2

AVERAGE FRESH AND DRY WEIGHTS, AND PERCENTAGE DRY MATTER OF FIVE TOMATO PLANTS AT VARIOUS STAGES OF GROWTH

\begin{tabular}{l|r|r|c}
\hline \multirow{2}{*}{$\begin{array}{l}\text { Stages } \\
\text { of Growth }\end{array}$} & \multicolumn{2}{|c|}{ Weight in Grams } & $\begin{array}{c}\text { Percentage } \\
\text { Dry Matter }\end{array}$ \\
\cline { 2 - 4 } & Fresh & Dry & \\
\hline Seedling & 72.3 & 4.7 & 6.50 \\
$\begin{array}{l}\text { Stem } \\
\text { Elongation }\end{array}$ & 150.1 & 10.2 & 6.82 \\
Flowering & 521.8 & 36.6 & 7.00 \\
Fruit & & & 8.86 \\
Setting & 1283.7 & 113.8 & 8.98 \\
Fruit & 2118.2 & 190.1 & \\
Enlargement & & & \\
\hline
\end{tabular}


Flgure 2. Percentage distribution of the plant ary weight at the following stages of growth: (1) Seedling; (2)

Stem elongation; (3) Flowering; (4) Fruit setting; (5) Fruit enlargement. 


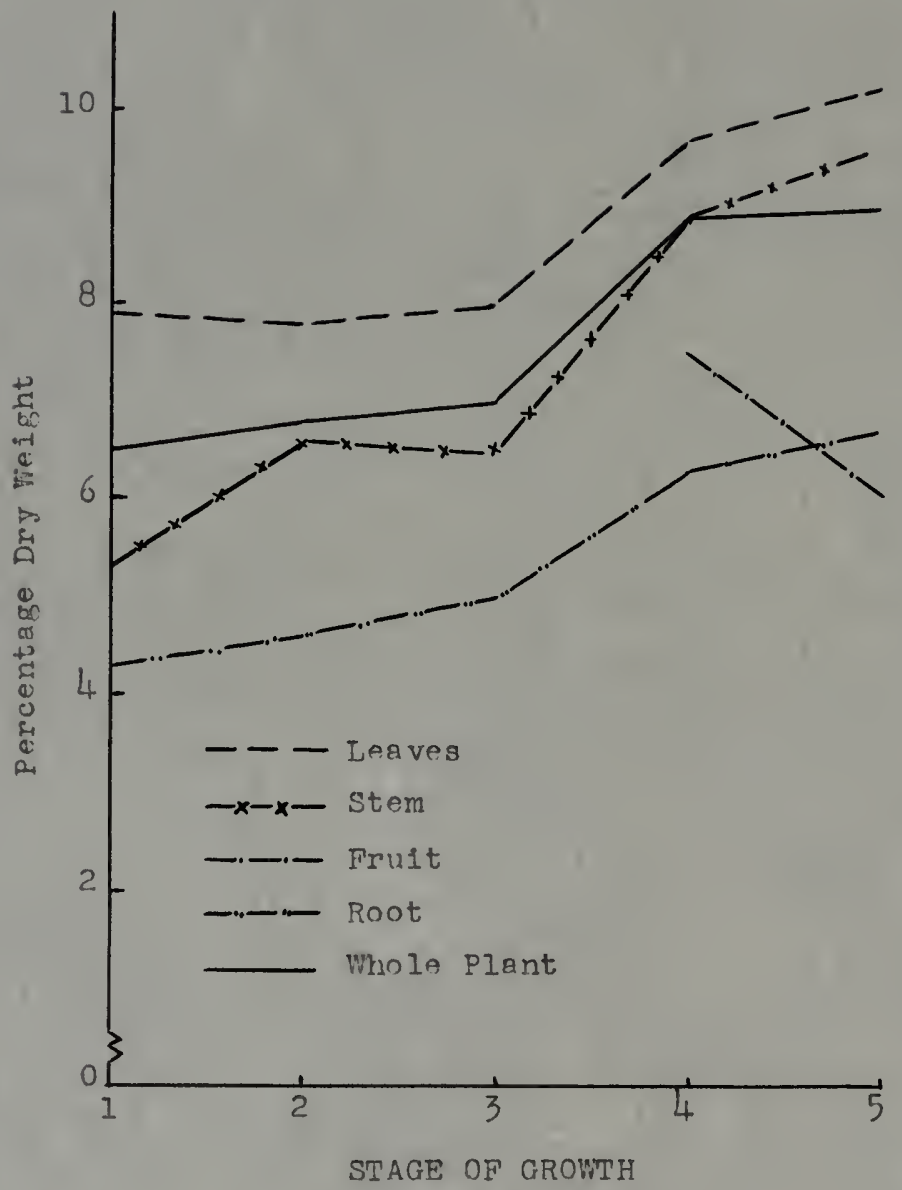


matter (21), it may seem reasonable to expect that the percentage of dry matter of the plant does not change apprec1ably during the last two stages of growth. On the other hand, the rapid accumulation of dry material that is found between the flowering and the fruit setting stages is in agreement with the opinion of Gile and Carrero (17) who found that in rice the percentage of dry matter did not rise unt1l the plant had begun to form seeds. Another observation is that the leaves form the portion of the plant that follows more closely the changes affecting the percentage of dry matter of the whole plant throughout the stages of its growth. It may also be added that the leaves show the highest percentage of dry matter as compared to the other portions of the plant.

\section{Potassium}

The rate of absorption of potassium expressed on a fresh, or dry welght basis (Table 3) is found to decrease with age. The analysis of variance (Table 4) indicates that the reduction in the rate of absorption from one stage to another is significant at the $1 \%$ level, as shown by the highly significant linear effect and non-significant quadratic effect and residual variation between stages. Since both polynomial regressions (F1gure 3) show the same characteristic slope, it may be concluded that no significant difference could be detected in the way of expressing the 


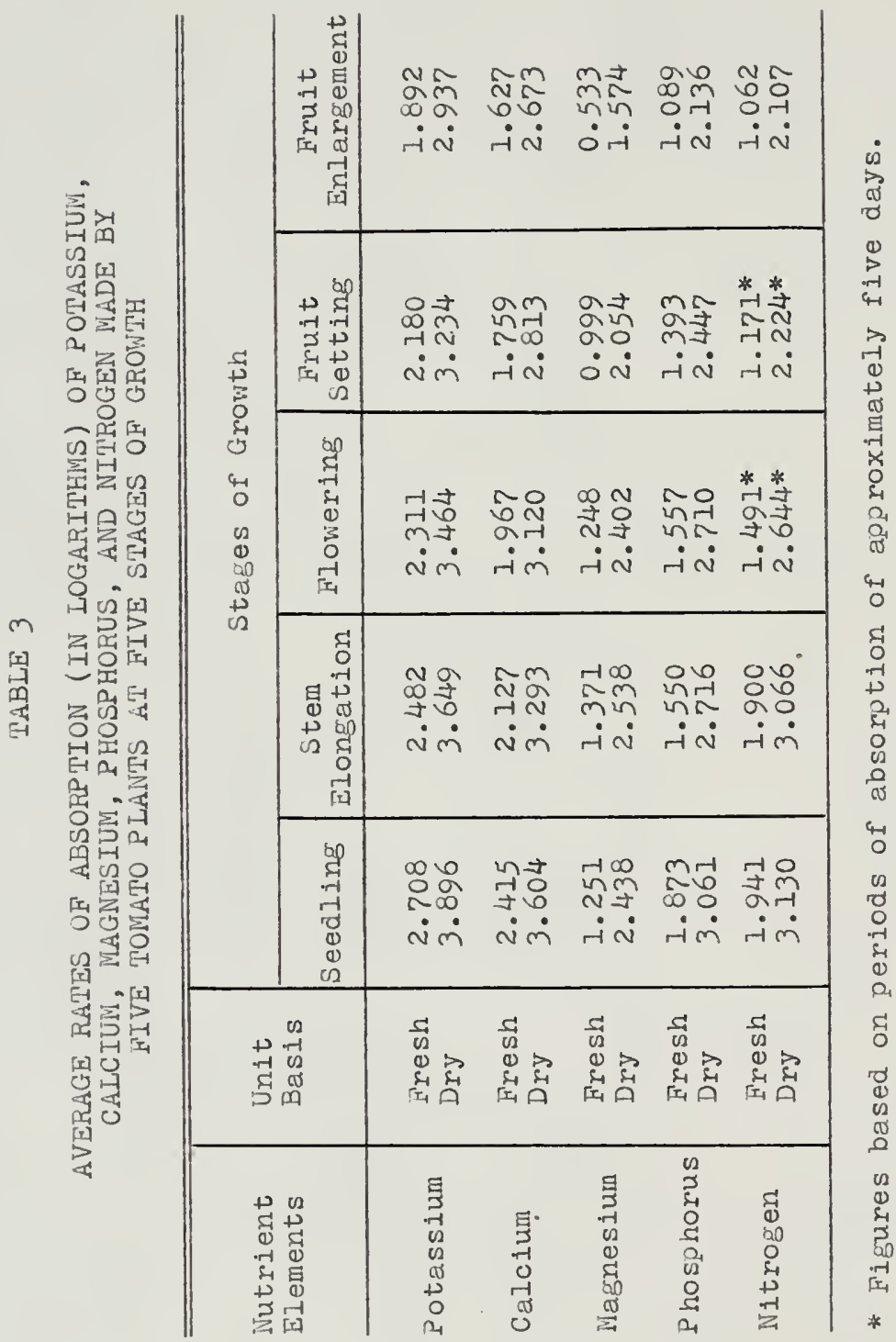


TABLE 4

ANALYSIS OF VARIANCE OF THE DATA (IN LOGARITHRS) FOR THE RATE OF ABSORPTION OF POTASSIUM EXPRESSED ON FRESH, OR DRY WEIGHT BASIS OF THE WHOLE PLANTI

Fresh Weight Basis

\begin{tabular}{l|r|r|r|c}
\hline Source of Variation & $\begin{array}{c}\text { Degrees } \\
\text { Freedom }\end{array}$ & $\begin{array}{c}\text { Sum of } \\
\text { Squares }\end{array}$ & $\begin{array}{c}\text { Vean } \\
\text { Square }\end{array}$ & $F$ \\
\hline Treatments ${ }^{2}$ & 4 & 1.898 & 0.475 & $52.8 * *$ \\
$\quad$ Linear Effect & 1 & 1.871 & 1.871 & $207.9 * *$ \\
Quadratic Effect & 1 & 0.003 & 0.003 & 0.3 \\
$\quad$ Residual & 2 & 0.024 & 0.012 & 1.3 \\
Replications & 4 & 0.031 & 0.008 & 0.9 \\
Error Total & 16 & 0.147 & 0.009 & \\
& 24 & 2.076 & & \\
\hline
\end{tabular}

Dry Weight Basis

Treatments ${ }^{2}$

Linear Effect Guadratic Effect Residual

Replications Error Total

\begin{tabular}{ll|l|l|l} 
& 4 & 2.735 & 0.547 & $54.7^{* *}$ \\
1 & & 2.719 & 2.719 & $271.9 * *$ \\
1 & & 0.007 & 0.007 & 0.7 \\
2 & & 0.009 & 0.005 & 0.5 \\
& 4 & 0.052 & 0.013 & 1.3 \\
16 & 0.153 & 0.010 & \\
24 & 2.940 & &
\end{tabular}

1 The calculations are given in the Appendix.

2 The differencesbetween any two consecutive treatments (stages of growth) are also significant at the $1 \%$ level.

* Significant at the $1 \%$ level. 
Figure 3. Rates of absorption of potassium at the following stages of growth: (1) Seedling; (2) Stem elongation; (3) Flowering; (4) Fruit setting; (5) Fruit enlargement. (The points on the curves represent the observed mean values.) 


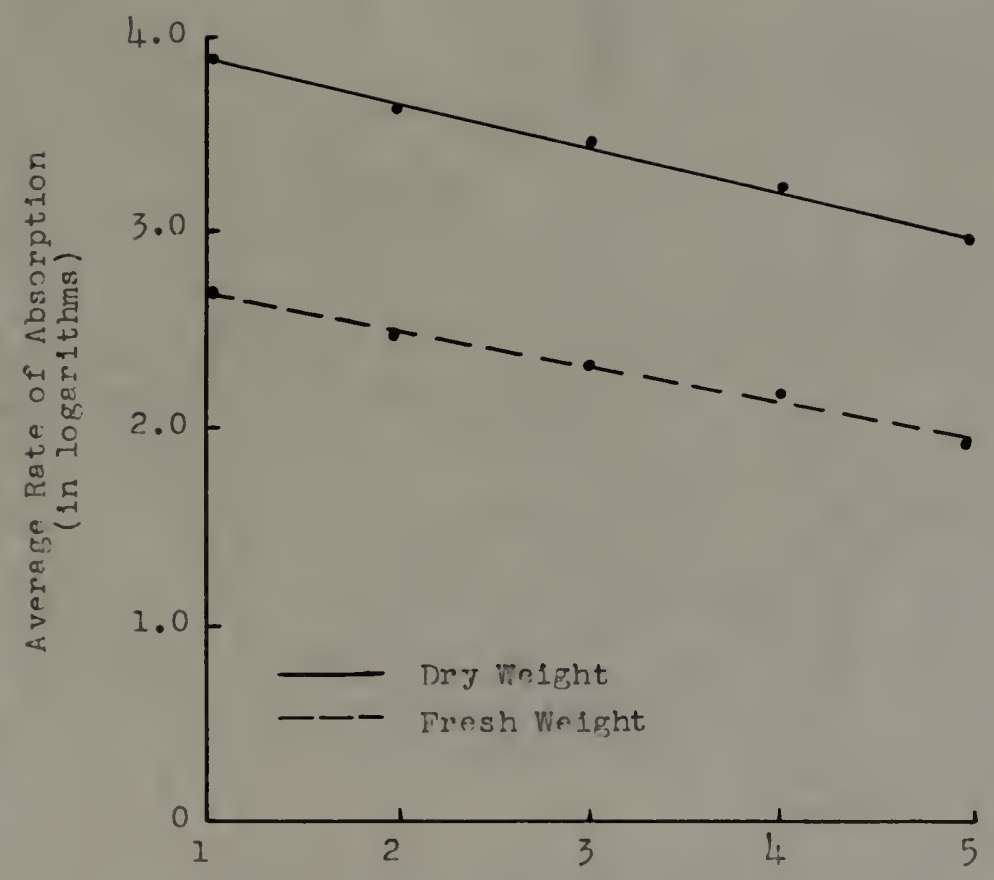

STAGE OF GROWH 
rate of absorption of this element. The fact that the rate of absorption of potassium is higher during the early stages of growth of the tomato plant is found to agree with the idea sustained by several workers $(8,12,13,14,17,18)$.

\section{Calcium}

The decrease in the rate of absorption of calcium (Table 3) on fresh, or ary weight basis also takes place throughout the life cycle of the tomato plant. The analysis of variance (Table 5) indicates that the decrease in rate is significant at the $1 \%$ level, as shown by the highly significant linear effect and non-significant quadratic effect and residual varlation between stages of growth. The trend of the rate of absorption of calcium on a fresh, or dry weight basis is found to show the same characteristic slope (Figure 4); as it was the case for potassium, the rate of absorption of calcium can be equally determined on either fresh, or dry weight basis. Apparently, the tomato plant also has a tendency to absorb large amounts of calcium during the early stages of growth.

\section{Magnesium}

Even though the overall tendency for the rate of absorption of magnesium is to decrease with maturation of the plant (Table 3), from the analysis of varlance is deduced that the variations in the rate of absorption are different among the stages of growth as indicated by the 
TABLE 5

ANALYSIS OF VARIANCE OF THE DATA (IN LOGARITHIS) FOR THE RATE OF ABSORPIION OF CALCIUM EXPRESSED ON FRESH, OR DRY WEIGHT BASIS OF THE WHOLE PLANTI

Fresh Weight Basis

\begin{tabular}{|c|c|c|c|c|}
\hline Source of Variation & $\begin{array}{l}\text { Degrees } \\
\text { Freedom }\end{array}$ & $\begin{array}{l}\text { Sum of } \\
\text { Squares }\end{array}$ & $\begin{array}{l}\text { Mean } \\
\text { Square }\end{array}$ & $F$ \\
\hline Treatments ${ }^{2}$ & 4 & 1.923 & 0.481 & $30.1 * *$ \\
\hline $\begin{array}{l}\text { Linear Effect } \\
\text { Quadratic Effect } \\
\text { Residual }\end{array}$ & $\begin{array}{l}\frac{1}{1} \\
2\end{array}$ & $\begin{array}{l}1.890 \\
0.025 \\
0.008\end{array}$ & $\begin{array}{l}1.890 \\
0.025 \\
0.004\end{array}$ & $\begin{array}{c}118.1^{* *} \\
1.6 \\
0.2\end{array}$ \\
\hline Replications & 4 & 0.077 & 0.019 & 1.2 \\
\hline Error & 16 & 0.254 & 0.016 & \\
\hline Total & 24 & 2.254 & & \\
\hline
\end{tabular}

Dry Weight Basis

Treatments ${ }^{2}$

Linear Effect

Quadratic Effect

Residual

Keplications

Error

Total

\begin{tabular}{|cc|c|c|c}
\hline & 4 & 2.782 & 0.696 & $43.5^{* *}$ \\
1 & & 2.744 & 2.744 & $171.5^{* *}$ \\
2 & & 0.015 & 0.015 & 0.9 \\
& & 0.023 & 0.012 & 0.8 \\
& 4 & 0.097 & 0.024 & 1.5 \\
& 16 & 0.251 & 0.016 & \\
\hline & 3.130 & & \\
\hline
\end{tabular}

1 The calculations are glven in the Appendix.

The differencesbetween any two consecutive treatments (stages of growth) are also significant at the 1\% level.

* Significant at the $1 \%$ level. 
F1gure 4. Rates of absorption of calclum at the following stages of growth: (1) Seedling; (2) Stem elongation; (3) Flowering; (4) Fruit setting; (5) Fruit enlargement. (The points on the curves represent the observed mean values.) 


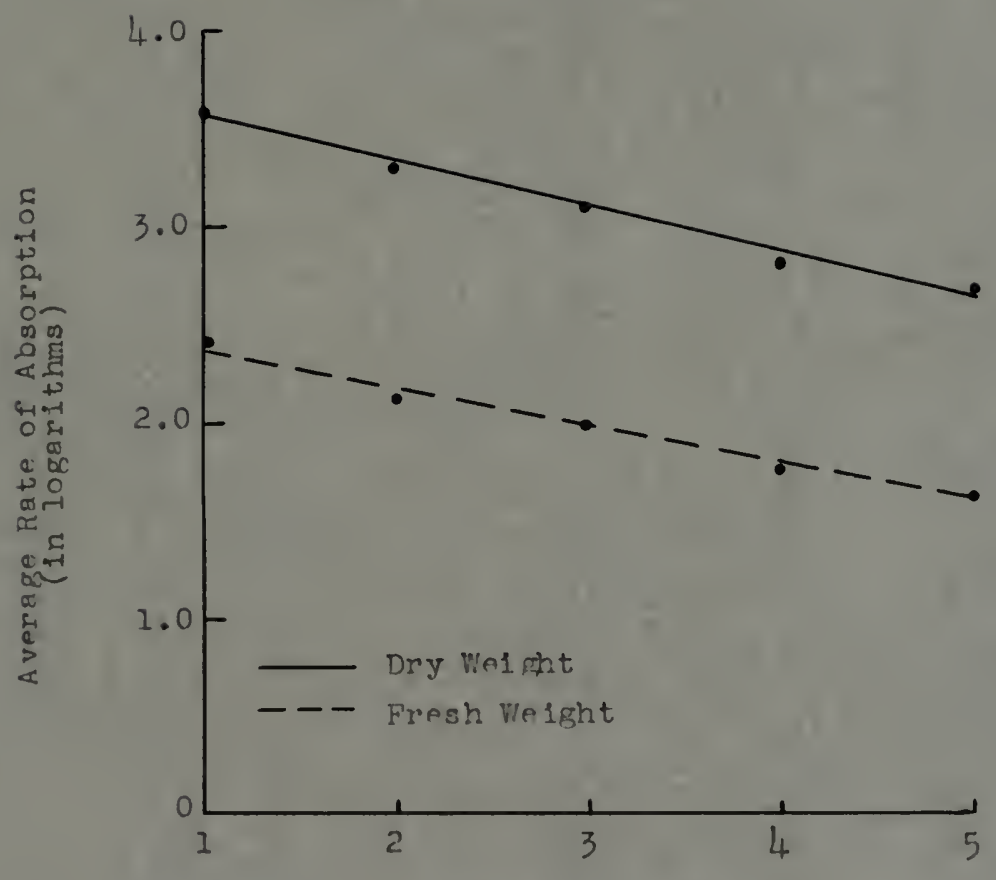

STAGE OF GROWTH 
significant linear and quadratic effects and non-significant residual variation between stages (Table 6). The trend of the rate of absorption of magnesium (Figure 5) shows that the rate tends to increase, although not significantly at the $5 \%$ level, between the seedling and the stem elongation stages; soon after this stage is passed the trend starts to decrease up to the last stage of growth. When the rate is expressed on ary weight basis, all the reductions are significant at the $1 \%$ level, but if the rate is expressed on fresh weight basis the decrease between the stem elongation and the flowering stages is not significant at the $5 \%$ level (Table 7 ). This divergency observed between the two rates at this point may be due to differences in the accumulation of fresh and dry matter by the plant at the flowering stage which show up only when the nutrient elements are absorbed in relatively small proportions during the vegetative stages of the development of the tomato plant. A similar case to this of magnesiurn will be also observed for the rates of absorption of phosphorus.

To test the significance of the difference between any two consecutive stages of growth it was necessary to develop a new technique* which involves the use of a t-test. The steps followed in testing the significance of

*The technique was developed by Dr. David B. Duncan, professor of Statistics of the University of Florida, based on an idea suggested by the writer. 
TABLE 6

ANALYSIS OF VARIANCE OF THE DATA (IN LOGARITHMS) FOR THE RATE OF ABSORPTION OF MAGNESIUM EXPRESSED ON FRESH, OR DRY WEIGHI BASIS OF THE WHOLE PLANTI

Fresh Weight Basis

\begin{tabular}{l|r|c|c|c}
\hline Source of Variation & $\begin{array}{r}\text { Degrees } \\
\text { Freedom }\end{array}$ & $\begin{array}{c}\text { Sum of } \\
\text { Squares }\end{array}$ & $\begin{array}{c}\text { Mean } \\
\text { Square }\end{array}$ & $F$ \\
\hline Treatments & 4 & 2.238 & 0.560 & $7.6^{* *}$ \\
$\quad$ Linear Effect & 1 & 1.636 & 1.636 & $\begin{array}{c}22.1^{* *} \\
\text { Quadratic Effect }\end{array}$ \\
Residual & 2 & 0.601 & 0.601 & $8.1^{*}$ \\
Replications & & 0.002 & 0.001 & 0.01 \\
Error Total & & 0.073 & 0.018 & 0.24 \\
& 16 & 1.176 & 0.074 & \\
& 24 & 3.487 & & \\
\hline
\end{tabular}

Dry Welght Basis

Treatments

Linear Effect

Quadratic Effect Residual

Replications

Error

Total

\begin{tabular}{ll|l|l|l} 
& 4 & 3.122 & 0.780 & $10.4 * *$ \\
1 & & 2.446 & 2.446 & $32.6 * *$ \\
1 & & 0.671 & 0.671 & $8.9 * *$ \\
2 & & 0.005 & 0.003 & 0.04 \\
& 4 & 0.087 & 0.022 & 0.3 \\
16 & 1.207 & 0.075 & \\
24 & 4.416 & &
\end{tabular}

1 The calculations are given in the Appendix.

* Significant at the 5\% level.

* Significant at the $1 \%$ level. 
F1gure 5. Rates of absorption of magnesium at the following stages of growth: (1) Seedling; (2) Stem elongation; (3) Flowering; (4) Fruit setting; (5) Fruit enlargement. (The points on the curves represent the observed mean values.) 




STAGE OF GRO:H 
TABLE $?$

SIGNIFICANCE OF THE DIFFERENCES BETWEEN ANY TWO CONSECUTIVE TREATMENT MEANS (STAGES OF GROWTH)

ON THE RESPECTIVE POLYNONIAL REGRESSIONS FOR THE RATE OF ABSORPTION OF MAGNESIUM

\begin{tabular}{|c|c|c|c|c|}
\hline \multirow{2}{*}{ Stage of Growth } & \multicolumn{2}{|c|}{ Fresh Weight Basis } & \multicolumn{2}{|c|}{ Dry Weight Basis } \\
\hline & $\begin{array}{c}\text { Difference } \\
|\mathrm{a}|\end{array}$ & $" t "$ & $\begin{array}{c}\text { Difierence } \\
|\mathrm{a}|\end{array}$ & " $t$ " \\
\hline $\begin{array}{l}\text { Seedling- } \\
\text { Stem Elongation }\end{array}$ & 0.098 & 0.93 & 0.073 & 0.69 \\
\hline $\begin{array}{l}\text { Stem Elongation- } \\
\text { slowering }\end{array}$ & 0.088 & 1.73 & 0.123 & $2.4 * *$ \\
\hline $\begin{array}{l}\text { Flowering- } \\
\text { Fruit Setting }\end{array}$ & 0.274 & $5.4 * *$ & 0.319 & $6.3 * *$ \\
\hline $\begin{array}{l}\text { Fruit Setting- } \\
\text { Fruit Enlargement }\end{array}$ & 0.460 & $4.4 * *$ & 0.515 & $4.8 * *$ \\
\hline
\end{tabular}

**Significant at the 1\% level. 
those differences are 1llustrated in some detail in the Appendix.

\section{Phosphorus}

The rate of absorption of phosphorus (Table 3) also has the tendency to decrease as the plant grows older. The analysis of variance (Table 8 ) indicates that the rate of absorption of this element, expressed on a fresh, or dry weight basis has an overall tendency to decrease, and the varlations among the stages are different as shown by the highly significant linear and cubic effects and the nonsignificant residual variation between stages. The trend of the rate of absorption of phosphorus (F1gure 6 and Table 9) indicates that the rate, when expressed on a dry weight basis, decreases significantly at the $1 \%$ level up to the last stage of growth, but a tendency for the rate to level off is observed between the stem elongation and fruit setting stages. This flattening is better shown by the curve for the rate of absorption on fresh weight basis. In either case, the leveling of the curves indicates that the tomato plant absorbed more phosphorus when it was blooming and setting fruit.

\section{Nitrogen}

Since the data for the absorption of nitrogen could not be analyzed statistically, it was impossible to get any results concerned with the rate of absorption of this 
TABLE 8

ANALYSIS OF VARIANCE OF THE DATA (IN LOGARITHMS) FOR THE RATE OF ABSORPTION OF PHOSPHORUS EXPRESSED ON FRESH, OR DRY WEIGHT BASIS OF THE WHOLE PLANTI

Fresh Weight Basis

\begin{tabular}{l|c|c|c|c}
\hline Source of Variation & $\begin{array}{c}\text { Degrees } \\
\text { Freedom }\end{array}$ & $\begin{array}{c}\text { Sum of } \\
\text { Squares }\end{array}$ & $\begin{array}{c}\text { Nean } \\
\text { Square }\end{array}$ & $F$ \\
\hline Treatments & 4 & 1.624 & 0.406 & $40.6 * *$ \\
$\quad$ Linear Effect & 1 & 1.487 & 1.487 & $148.7^{* *}$ \\
$\quad$ Quadratic Effect & 1 & 0.006 & 0.006 & 0.6 \\
$\quad$ Cubic Effect & 1 & 0.110 & 0.110 & $11.0^{* *}$ \\
$\quad$ Residual & 1 & 0.021 & 0.021 & 2.1 \\
Replications & 4 & 0.006 & 0.002 & 0.2 \\
Error Total & 16 & 0.161 & 0.010 & \\
& 24 & 1.791 & & \\
\hline
\end{tabular}

Dry Weight Basis

Treatments

Inear Effect Quadratic Effect Cubic Effect Residual

Keplications

Error

Total

\begin{tabular}{cc|c|c|c} 
& 4 & 2.381 & 0.595 & $45.8 * *$ \\
1 & & 2.248 & 2.248 & $172.9 * *$ \\
1 & & 0.013 & 0.013 & 1.0 \\
1 & & 0.074 & 0.074 & $5.7 *$ \\
1 & & 0.046 & 0.046 & 2.0 \\
& 4 & 0.033 & 0.008 & 0.1 \\
16 & 0.203 & 0.013 & \\
24 & 2.617 & & \\
\hline
\end{tabular}

1 The caiculations are given in the Appendix.

* Significant at the 5\% level.

* Significant at the $1 \%$ level. 
Figure 6. Rates of absorption of phosphorus at the following stages of growth: (1) Seedling; (2) Stem elongation; (3) Flowering; (4) Fruit setting; (5) Fruit enlargement. (The points on the curves represent the observed mean values.) 


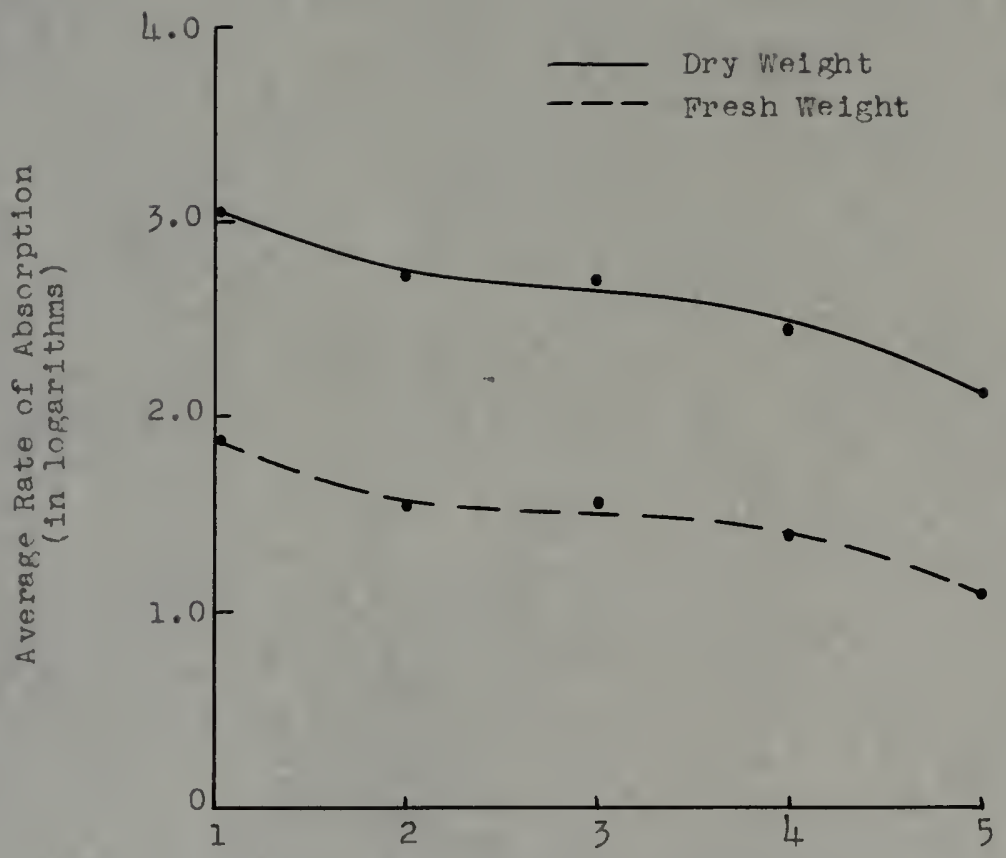

STAGE OF GROWIH 


\section{TABLE 9}

SIGNIFICANCE OF THE DIFFERENCES BETWEEN ANY TWO CONSECUTIVE TREATIENT MEANS (STAGES OF GROWTH) ON THE RESPECTIVE POLYNOMIAL REGRESSIONS FOR THE RATE OF ABSORPTION OF PHOSPHORUS

\begin{tabular}{|c|c|c|c|c|}
\hline \multirow{2}{*}{ Stage of Growth } & \multicolumn{2}{|c|}{ Fresh Welght Basis } & \multicolumn{2}{|c|}{ Dry Weight Basis } \\
\hline & $\begin{array}{c}\text { Difference } \\
|\mathrm{d}|\end{array}$ & $" t "$ & $\begin{array}{c}\text { Difference } \\
|\mathrm{d}|\end{array}$ & " $t$ " \\
\hline $\begin{array}{l}\text { Seedilng- } \\
\text { Stem Elongation }\end{array}$ & 0.286 & $4.2 * *$ & 0.287 & $4.4 * *$ \\
\hline $\begin{array}{l}\text { Stem Elongation- } \\
\text { Flowering }\end{array}$ & 0.069 & 1.7 & 0.120 & $3.1 * *$ \\
\hline $\begin{array}{l}\text { Flowering- } \\
\text { Fruit Setting }\end{array}$ & 0.087 & $2.2^{*}$ & 0.148 & $3.8 * *$ \\
\hline $\begin{array}{l}\text { Fruit Setting- } \\
\text { Fruit Enlargement }\end{array}$ & 0.340 & $5.0 * *$ & 0.371 & $5.6 * *$ \\
\hline
\end{tabular}

*Significant at the $5 \%$ Ievel. **Significant at the $1 \%$ level. 
element. Table 3 can only give a slight idea of the pattern of such absorption. 


\section{DISCUSSION}

In the light of the results obtained from this experiment it may be said that the nutrient elements potassium, calcium, magnesium, phosphorus, and probably nitrogen are absorbed selectively by the tomato plant throughout its iffe cycle.

Even though the plant absorbs the nutrients in larger amounts as it gets older, the amount taken up of each element on a unit weight basis decreases as the plant matures.

The rates of absorption of potassium and calcium were found to decrease uniformly with age, and the respective trends for the rates of absorption were found to be Iinear as indicated by the significant Iinear effect (at the $1 \%$ level) and non-significant quadratic effect and residual varlation between stages of growth.

The rate of absorption of magnesium showed an overall tendency to decrease with maturation of the plant, but the changes in rate from one stage to another were found to be different in significance; between the seedling and the stem elongation stages the rate had a tendency to increase although not significantly at the 5\% level; 
soon after the stem elongation stage the rate started to decrease significantly at the $1 \%$ level, if it was expressed on a dry weight basis; on the other hand, if the rate was expressed on a fresh weight basis, the decrease between the stem elongation and the flowering stages was not significant at the $5 \%$ level. The divergency observed between the rates at this point may be due to differences in the accumulation of fresh and dry matter by the plant at the flowering stage which showed up only when the nutrient elements were absorbed in relatively small proportions during the vegetative stages of growth of the tomato plant. A similar case to this was also observed for the rates of absorption of phosphorus.

The rate of absorption of phosphorus was also found to have an overall tendency to decrease with age. Nevertheless, the significant reductions in rate at the $1 \%$ level that were observed when the rate was expressed on the dry weight basis tended to level off somewhat between the stem elongation and the fruit setting stages. This tendency was more pronounced when the rate was expressed on a fresh weight basis. In either case, the flattening of the curves indicates that the tomato plant absorbed more phosphorus during the periods of blooming and setting of the fruit. Due to a shortage in supply of nitrogen at the flowering and fruit setting stages, the data for nltrogen could not be analyzed statistically. 
In every case, the fitted polynomial regressions of the rates of absorption on the stages of growth were found to be the best estimates of the respective trends, as indicated by the non-significant residual variation between stages of growth. 


\section{SUMMARY}

An experiment was set up to study the effect of maturation of the tomato plant upon the rates of absorption of potassium, calcium, magnesium, phosphorus, and nitrogen expressed on fresh or dry weight basis.

It was found that even though the tomato plant had a marked tendency to absorb the nutrient elements in larger amounts as it grew older, the rates of absorption per unit of fresh or dry weight basis had a general tendency to decrease throughout the life cycle.

The rates of absorption of potassium and calcium were found to decrease linearly throughout the five stages of growth under study. This linear decrease was statistically significant at the $1 \%$ level. The changes in rate were, therefore, also significant at the same level. The rate of absorption of magnesium was found to increase slightly from the seedling to the stem elongation stages, and then to decrease more and more through the later stages. Both the linear and the quadratic trends were statistically slgnificant at the $1 \%$ level. The increase in rate of absorption from the seeding to the stem elongation stages was not significant at the $5 \%$ level. The 
subsequent decreases, however, were all significant at the 1\% level except for the decrease between the stem elongation and the flowering stages, when the rate was expressed on fresh weight basis.

The rate of absorption of phosphorus followed a more complex curve. In general, there was a linear downward trend (significant at the $1 \%$ level) together with a tendency to level of between the stem elongation and the frult setting stages which indicates that the tomato plant absorbed more phosphorus between these two stages of growth. The departures from Iinearity gave a cublc trend which was significant at the $1 \%$ level.

The fitted polynomial regressions of the rates of absorption on the stages of growth of the tomato plant were found, under the conditions of this experiment, to be the best estimates for the respective trends.

The data for the absorption of nitrogen could not be analyzed statistically because of a variation introduced by a shortage in supply found at the flowering and fruit setting stages. 
APPENDIX 
I. METHODS FOR THE QUANTITATIVE ANALYSIS OF POTASSIUM, CALCIUM, MAGNESIUM, PHOSPHORUS AND NITROGEN

\section{Potassium $(22) *$}

Standard: Dry potassium chloride in the oven and weigh out exactly $0.3813 \mathrm{gr}$. Dissolve and make to one liter. This gives a standard of 200 p.p.m. For the working standard dilute to 20 p.p.m.

Procedure: (Using the Beckman Model B flame photometer.) Use the red phototube and 10,000 megohm resistor. Set sensitivity at 4 and wave length at $768 \mathrm{m \mu}$. Adjust dark current to zero until steady. Obtain a 100\% transmission using the potassium standard of $20 \mathrm{p} . \mathrm{p} . \mathrm{m}$. Place water into flame and record transmission. Place the sample into flame and record transmission.

To record: Subtract transmission of water from transmission of sample; look up results in standard curve and correct for dilution.

Standard Curve: Place 25, 50, 75, and 100 aliquots of the 20 p.p.m. potassium standard in $100 \mathrm{ml}$. volumetric flasks. 
Nake up to volume and read on pnotometer. This will give a curve for 5, 10, 15 and 20 p.p.m. Plot the net percentage transmission on plain graph paper.

\section{Calc1um $(22) *$}

Same procedure as for potassium except for:

1. Wave length $554 \mathrm{m \mu}$.

2. Blue phototube and 10,000 megohm resistor.

3. To avoid the interference of high concentrations of phosphorus in the readings for calclum, the nutrient solution has to be diluted so that the phosphorus concentration is around 2 p.p.m.

4. Working standard for calcium is 200 p.p.m.

Standard: Dry calcium chloride in the oven and weigh out exactly $0.5538 \mathrm{gr}$. Dissolve and make to one liter. This gives a standard of 200 p.p.m.

Standard Curve: Place 25, 50, 75, and $100 \mathrm{ml}$. aliquots of the 200 p.p.m. calcium standard in $100 \mathrm{ml}$. volumetric

flasks. Make up to volume and read on photometer. This will give a curve for 50, 100, 150 and 200 p.p.m. Plot the net percentage transmission on plain graph paper.

\section{Magnesium (23)*}

Reagents: Hydroxylamine hydrochloride $-5 \%$. Dissolve 
$10 \mathrm{gr}$. of the reagent in $200 \mathrm{ml}$. of water and store in dark bottle.

Sodium hydroxide $-2.5 \mathrm{~N}$. Dissolve $50 \mathrm{gr}$. of the reagent in $500 \mathrm{ml}$. of water.

Thiazole yellow - $0.02 \%$. Dissolve $0.10 \mathrm{gr}$. of the reagent in $500 \mathrm{ml}$. of water and store in dark bottle. Prepare fresh batch every 2 weeks.

Compensating solution. Dissolve $3.7 \mathrm{gr}$. of calcium chloride $\left(\mathrm{CaCl}_{2} \cdot 2 \mathrm{H}_{2} \mathrm{O}\right), 0.74 \mathrm{gr}$. eluminum sulfate $\left(\mathrm{Al}_{2}\left(\mathrm{SO}_{4}\right)_{3} \cdot 18 \mathrm{H}_{2} \mathrm{O}\right), 0.36 \mathrm{gr}$. manganous chloride $\left(\mathrm{MnCl}_{2} \cdot 4 \mathrm{H}_{2} \mathrm{O}\right)$, and $0.60 \mathrm{gr}$. sodium phosphate $\left(\mathrm{Na}_{3} \mathrm{PO}_{4}\right)$ in about $500 \mathrm{ml}$. of water containing $10 \mathrm{ml}$. of concentrated $\mathrm{HCl}$. Dilute to 1 I1ter.

Starch solution ${ }^{1}-2 \%$. Mix $50 \mathrm{ml}$. of glycerol and $50 \mathrm{ml}$. of water and bring to boll. Add a mixture of $1 \mathrm{gr}$. soluble starch with 2 to $3 \mathrm{ml}$. of water, stir, and continue the bolling for 3 minutes. Cool to room temperature and use or store. This starch solution may show no signs of deterioration after at least 6 months.

Starch Compensating reagent. Mix equal volumes of the starch solution and compensating solution. Prepare daily as needed.

Procedure: (Using the colorimetric set up of a Beckman 
Model B photometer.)

Transfer a $2 \mathrm{ml}$. aliquot of the nutrient solution to a $50 \mathrm{ml}$. volumetric flask and enough water to bring the volume to about $25 \mathrm{ml}$. Add $1 \mathrm{ml}$. of the hydroxilamine hydrochloride solution from a burette. Then add $5 \mathrm{ml}$. of starch compensating solution and shake well. Add exactly $5 \mathrm{ml}$. of thiazol yellow solution from a pipette and mix. Add $5 \mathrm{ml}$. of sodium hydroxide solution. Shake and bring to volume with water. Mix again and allow to stand about 15 minutes before reading on colorimeter at wave length $540 \mathrm{mu}$., sensitivity 1. Use a blue phototube and 500 megohm resistor. With each set mun a blank which is used for $100 \%$ transmission.

Standard Curve: Treat two $5 \mathrm{ml}$. aliquots of 20 p.p.m. standard magnesium solution in the same manner as the unknowns. This gives a 2 p.p.m. sample. The line passing through the origin point and the average reading of the two known samples constitutes the standard curve. Plot on semi-log paper if \% transmission is read, or on plain graph paper if optical density is read.

Standard: Dissolve $250 \mathrm{mg}$. of reagent grade magnesium metal in dilute hydrochloric acid solution $(150 \mathrm{ml}$. of water and $10 \mathrm{ml}$. of concentrated $\mathrm{HCl}$ ) and bring to volume in a $250 \mathrm{ml}$. volumetric flask. Dilute $10 \mathrm{ml}$. of this solution to $500 \mathrm{ml}$. for the working standard of $20 \mathrm{p} . \mathrm{p} . \mathrm{m}$. 
of magnesium.

\section{Phosphorus (24)*}

Reagents: Ammonium molybdate solution. Heat $25 \mathrm{gr}$. of the reagent in about $200 \mathrm{ml}$. of water at $60^{\circ} \mathrm{C}$. and filter. Dilute $280 \mathrm{ml}$. of concentrated sulfurlc acld to about $800 \mathrm{ml}$. When cool, add the ammonium molybdate solution to the sulfuric acid slowly with constant stirring. Cool the mixture, transfer to $1000 \mathrm{ml}$. volumetric flask and make up to volume. This is a $2.5 \%$ solution of ammonium molybdate in $10 \mathrm{~N} \mathrm{H}_{2} \mathrm{SO}_{4}$.

\section{$1,2,4$, aminonaphtholsulfonic ac1d. Dissolve}

$0.5 \mathrm{gr}$. of the reagent and $6 \mathrm{gr}$. of sodium sulfite in about $200 \mathrm{ml}$. of water. Add $30 \mathrm{gr}$. of sodium bisulfite and dissolve. Filter and make the final volume of $250 \mathrm{ml}$. Prepare a fresh batch at least every. two weeks.

Procedure: Transfer a $2 \mathrm{ml}$. aliquot of the nutrient solution into a $50 \mathrm{ml}$. volumetric flask. Add about 20 to $25 \mathrm{ml}$. of water and shake. Add $2 \mathrm{ml}$. of nolybdate solution from a burette and shake. Add $2 \mathrm{ml}$. of 1,2,4, aminonaphtholsulfonic acid also from burette and shake. Make up to volume, shake, and allow to stand 10 to 12 minutes before reading on colorimeter at wave length $700 \mathrm{mu}$. and sensitivity 3 against a blank for zero optical density. Use a blue phototube and 500 megohm resistor. 
Standard Curve: Transfer 1, 2, 4, and $10 \mathrm{ml}$. aliquots of the $10 \mathrm{p} . \mathrm{p} . \mathrm{m}$. phosphorus standard into $50 \mathrm{ml}$. volumetric flasks and proceed in the same manner as the unknowns. This will give a curve for $0.2,0.4,0.8$, and 2 p.p.m. Plot optical density on plain graph paper.

Standard: Dissolve $0.4394 \mathrm{gr}$. of $\mathrm{KH}_{2} \mathrm{PO}_{4}$ (dried over sulfuric acid) in water. Add $10 \mathrm{ml}$. of $1: 3 \mathrm{H}_{2} \mathrm{SO}_{4}$ and dilute to 1 liter. This solution contains $100 \mathrm{p} . \mathrm{p} . \mathrm{m}$. of phosphorus equivalent to $229 \mathrm{p} . \mathrm{p} . \mathrm{m}$. of $\mathrm{P}_{2} \mathrm{O}_{5}$. Dilute $100 \mathrm{ml}$. of this solution to 1 liter, thus making a standard solution of 10 p.p.m.

\section{Micro-Kjeldahl-Gunning Method}

Total nitrogen is determined by this method to include nitrates anā nitrites.

Reagents: Concentrated sulfuric acid with $34 \mathrm{gr}$. of salycilic acid per liter.

Sodium thiosulfate, $50 \mathrm{mg}$.

Sodium hydroxide solution. Dissolve $400 \mathrm{gr}$. per liter.

Boric acid, $2 \%$.

$0.02 \mathrm{~N}$ standardized $\mathrm{HCl}$.

Catalyst. $\mathrm{Mix} 2$ parts of $\mathrm{CuSO}_{4}$ and 1 part of

$\mathrm{K}_{2} \mathrm{SO}_{4}$ 
Indicator:

$$
\begin{aligned}
& \text { Methylene blue, } 0.248 \mathrm{gr} \text {. } \\
& \text { Methyl red, } 0.375 \mathrm{gr} \text {. } \\
& \text { Ethanol } 95 \%, 300 \mathrm{ml} \text {. }
\end{aligned}
$$

Procedure: Transfer $20 \mathrm{ml}$. aliquots of nutrient solution to $30 \mathrm{ml}$. Kjeldahl flask. Add $2 \mathrm{ml}$. of the sulfuric acid and salycilic acid to the sample, stopper and allow to stand at least 30 minutes. Add approximately $50 \mathrm{mg}$. of sodium thiosulfate, place on Kjeldahl rack, heat 5 minutes over a low flame and cool. Add a knife point of catalyst, $\mathrm{mix}$ and heat gently until the reaction subsides. Prevent any loss of the material due to frothing. When frothing has ceased, increase heat so that a sulfuric acid condensation ring is formed in the neck of the flask. Continue digestion until the liquid becomes water-white.

Distillation is carried out as follows: The micro st1ll is thoroughly cleaned out by allowing steam to pass through for 10 or 15 minutes. Open all stopcocks, place a $150 \mathrm{ml}$. beaker containing $10 \mathrm{ml}$. of boric acid solution, $20 \mathrm{ml}$. of water, and a few drops of the indicator, under the condenser. Have the water in the steam generator hot. Transfer the digested material to the distillation flask, using $40 \mathrm{ml}$. of water. Add $10 \mathrm{ml}$. of sodium hydroxide solution, put flame under steam generator and close the stopcocks. All the ammonia is distilled over in 5 minutes 
from the time the first distillate appears.

Titrate the solution to color produced by $10 \mathrm{ml}$. of boric acid and same amount of indicator made to approximate the volume of distillate.

$$
\text { p.p.m. } N=\frac{(\mathrm{ml} . \mathrm{HCl})(\text { Normality } \mathrm{HCl})(14)(1000)}{\text { Volume of sample in } \mathrm{ml}}
$$


II. TOTAL CONCENTRATIONS OF THE VARIOUS NUTRIENT ELEMENTS SUPPLIED IN EIGHT LITERS OF SOLUTION TO FIVE TOIATTO PLANTS AT FIVE STAGES OF GROWTH

\begin{tabular}{|c|c|c|c|c|c|}
\hline \multirow[b]{2}{*}{$\begin{array}{l}\text { Repli- } \\
\text { cations }\end{array}$} & \multicolumn{5}{|c|}{ Stages of Growth } \\
\hline & 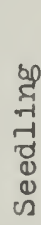 & 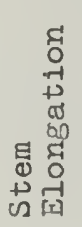 & 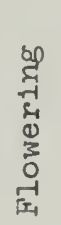 & & 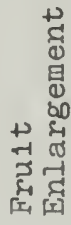 \\
\hline
\end{tabular}

Potassium

\begin{tabular}{c|r|r|r|r|r}
\hline 1 & 420.0 & 410.4 & 1112.0 & 1504.0 & 1488.0 \\
2 & 240.0 & 500.0 & 988.0 & 2240.0 & 1520.0 \\
3 & 260.0 & 460.0 & 1316.0 & 1816.0 & 1896.0 \\
4 & 460.0 & 440.0 & 912.0 & 1976.0 & 1608.0 \\
5 & 540.0 & 460.0 & 1024.0 & 2256.0 & 1696.0 \\
Total.. & 1920.0 & 2270.4 & 5352.0 & 9792.0 & 8208.0 \\
\hline
\end{tabular}

Calcium

\begin{tabular}{c|r|r|r|r|r}
\hline 1 & 100.0 & 200.0 & 320.0 & 720.0 & 680.0 \\
2 & 320.0 & 200.0 & 440.0 & 840.0 & 800.0 \\
3 & 220.0 & 200.0 & 800.0 & 824.0 & 1320.0 \\
4 & 100.0 & 200.0 & 440.0 & 720.0 & 840.0 \\
5 & 320.0 & 200.0 & 520.0 & 600.0 & 920.0 \\
Total.. & 1060.0 & 1000.0 & 2520.0 & 3704.0 & 4560.0 \\
\hline
\end{tabular}

Magnesium

\begin{tabular}{c|r|r|r|r|r}
\hline 1 & 29.6 & 41.6 & 90.4 & 59.2 & 66.4 \\
2 & 4.0 & 24.8 & 104.8 & 131.2 & 120.8 \\
3 & 18.4 & 49.6 & 95.2 & 175.2 & 86.4 \\
4 & 32.0 & 29.6 & 60.0 & 123.2 & 36.8 \\
5 & 4.8 & 35.2 & 121.6 & 204.0 & 70.4 \\
Total.. & 88.8 & 180.8 & 472.0 & 692.8 & 380.8 \\
\hline
\end{tabular}


II. (continued)

Nitrogen

\begin{tabular}{c|r|r|r|r|r}
\hline 1 & 53.6 & 92.0 & $259.2^{*}$ & $148.0 *$ & 258.4 \\
2 & 59.2 & 124.0 & $146.4^{*}$ & $221.6 *$ & 259.2 \\
3 & 64.8 & 146.4 & $127.2^{*}$ & $156.0^{*}$ & 245.6 \\
4 & 52.0 & 123.2 & $180.8^{*}$ & $221.6 *$ & 220.0 \\
5 & 89.6 & 113.6 & $123.2^{*}$ & $216.0^{*}$ & 228.8 \\
Total.. & 319.2 & 599.2 & 836.8 & 963.2 & 1212.0 \\
\hline
\end{tabular}

Phosphorus

\begin{tabular}{c|r|r|r|r|r}
\hline 1 & 62.4 & 42.4 & 178.4 & 216.8 & 260.8 \\
2 & 45.6 & 53.6 & 180.8 & 393.6 & 376.0 \\
3 & 48.8 & 69.6 & 240.8 & 322.4 & 236.8 \\
4 & 63.2 & 56.0 & 158.4 & 323.2 & 146.4 \\
5 & 49.6 & 47.2 & 185.6 & 355.2 & 337.6 \\
Total. & 269.6 & 268.8 & 944.0 & 1611.2 & 1357.6 \\
\hline
\end{tabular}

* Figures based on periods of absorption of approximately five days. 
III. HOAGLAND'S NO. 2 FORMULA FOR NUTRIENT SOLUTION (25)*

A.

$\begin{array}{lc}\mathrm{Ca}\left(\mathrm{NO}_{3}\right)_{2} \cdot 4 \mathrm{H}_{2} \mathrm{O} & \mathrm{gm} / \text { Iiter } \\ \mathrm{KNO}_{3} & 0.95 \\ \mathrm{MgSO}_{4} \cdot 7 \mathrm{H}_{2} \mathrm{O} & 0.61 \\ \mathrm{NH}_{4} \mathrm{H}_{2} \mathrm{PO}_{4} & 0.49\end{array}$

B. Composition of the stock solution that supplied the minor elements:

\begin{tabular}{|c|c|}
\hline $\mathrm{H}_{3} \mathrm{BO}_{3}$ & 0.915 \\
\hline $\mathrm{MnSO}_{4} \cdot 2 \mathrm{H}_{2} \mathrm{O}$ & 0.543 \\
\hline $\mathrm{ZnSO} 4 \cdot 7 \mathrm{H}_{2} \mathrm{O}$ & 0.07 \\
\hline $\mathrm{CuSO}_{4} \cdot 5 \mathrm{H}_{2} \mathrm{O}$ & 0.0 \\
\hline
\end{tabular}

C. Sequestrene $\mathrm{NaFe} \quad \mathbf{1 3 . 4}$

$25 \mathrm{ml}$. of solutions $\mathrm{B}$ and $\mathrm{C}$ were added to each crock containing 8 liters of nutrient solution. 
IV. FRESH AND DRY WEIGHTS (IN GRAMS) AND PERCENTAGE DRY MATTER OF THE PORTIONS, AS WELL AS THE WHOLE PLANT, OF FIVE TOMATO PLANTS AT FIVE STAGES OF GROWTH

\begin{tabular}{|c|c|c|c|c|c|c|}
\hline \multicolumn{7}{|c|}{ Seedling Stage } \\
\hline \multirow{2}{*}{$\begin{array}{l}\text { Plant } \\
\text { No. }\end{array}$} & \multicolumn{3}{|c|}{ IEAVES } & \multicolumn{3}{|c|}{ STEIY } \\
\hline & $\begin{array}{l}\text { Fresh } \\
\text { Weight }\end{array}$ & $\begin{array}{c}\text { Dry } \\
\text { Weight }\end{array}$ & $\begin{array}{l}\text { Percentage } \\
\text { Dry Matter }\end{array}$ & $\begin{array}{l}\text { Fresh } \\
\text { Weight }\end{array}$ & $\begin{array}{l}\text { Dry } \\
\text { Weight }\end{array}$ & $\begin{array}{l}\text { Percentage } \\
\text { Dry Matter }\end{array}$ \\
\hline $\begin{array}{r}I \\
I I \\
I I I \\
I V \\
V\end{array}$ & $\begin{array}{l}30.9 \\
36.9 \\
43.2 \\
45.0 \\
49.4\end{array}$ & $\begin{array}{l}2.4 \\
2.9 \\
3.8 \\
3.7 \\
3.4\end{array}$ & $\begin{array}{l}7.77 \\
7.86 \\
8.80 \\
8.22 \\
6.84\end{array}$ & $\begin{array}{l}11.3 \\
12.8 \\
14.7 \\
14.1 \\
16.9\end{array}$ & $\begin{array}{r}0.6 \\
.7 \\
.9 \\
.8 \\
.8\end{array}$ & $\begin{array}{l}5.31 \\
5.47 \\
5.44 \\
5.67 \\
4.73\end{array}$ \\
\hline Ave.. & 41.1 & 3.4 & 7.90 & 14.0 & .8 & 5.32 \\
\hline & \multicolumn{3}{|c|}{ ROOT } & \multicolumn{3}{|c|}{ WHOLE PIANT } \\
\hline $\begin{array}{r}I \\
I I \\
I I I \\
I V \\
V\end{array}$ & $\begin{array}{l}14.9 \\
18.5 \\
20.1 \\
13.0 \\
19.3\end{array}$ & $\begin{array}{r}0.6 \\
.7 \\
.8 \\
.7 \\
.8\end{array}$ & $\begin{array}{l}4.00 \\
3.78 \\
3.98 \\
5.38 \\
4.14\end{array}$ & $\begin{array}{l}57.1 \\
68.2 \\
78.0 \\
72.1 \\
85.9\end{array}$ & $\begin{array}{l}3.6 \\
4.3 \\
5.5 \\
5.2 \\
5.0\end{array}$ & $\begin{array}{l}6.30 \\
6.30 \\
7.05 \\
7.21 \\
5.82\end{array}$ \\
\hline Ave.. & 17.2 & .7 & 4.26 & 72.3 & 4.7 & 6.50 \\
\hline
\end{tabular}


IV. (continued)

Stem Elongation Stage

\begin{tabular}{|c|c|c|c|c|c|c|}
\hline \multirow[b]{2}{*}{$\begin{array}{l}\text { Plant } \\
\text { No. }\end{array}$} & \multicolumn{3}{|c|}{ LEAVES } & \multicolumn{3}{|c|}{ STEM } \\
\hline & $\begin{array}{l}\text { Fresh } \\
\text { Weight }\end{array}$ & $\begin{array}{c}\text { Dry } \\
\text { Weight }\end{array}$ & $\begin{array}{l}\text { Percentage } \\
\text { Dry Matter }\end{array}$ & $\begin{array}{l}\text { Fresh } \\
\text { Weight }\end{array}$ & $\begin{array}{c}\text { Dry } \\
\text { Weight }\end{array}$ & $\begin{array}{l}\text { Percentage } \\
\text { Dry Matter }\end{array}$ \\
\hline $\begin{array}{r}I \\
\text { II } \\
\text { III } \\
\text { IV } \\
\mathrm{V}\end{array}$ & $\begin{array}{r}74.5 \\
94.0 \\
100.0 \\
87.5 \\
85.5\end{array}$ & $\begin{array}{l}5.5 \\
7.5 \\
8.2 \\
7.1 \\
6.4\end{array}$ & $\begin{array}{l}7.38 \\
7.98 \\
8.20 \\
8.16 \\
7.49\end{array}$ & $\begin{array}{l}22.5 \\
23.5 \\
24.5 \\
22.5 \\
23.5\end{array}$ & $\begin{array}{l}1.4 \\
1.6 \\
1.7 \\
1.5 \\
1.5\end{array}$ & $\begin{array}{l}6.22 \\
6.81 \\
6.94 \\
6.67 \\
6.38\end{array}$ \\
\hline Ave.. & 88.2 & 6.9 & 7.84 & 23.3 & 1.5 & 6.60 \\
\hline \multicolumn{4}{|c|}{ ROOT } & \multicolumn{3}{|c|}{ WHOLE PLANT } \\
\hline $\begin{array}{r}\text { I } \\
\text { II } \\
\text { III } \\
\text { IV } \\
\mathrm{V}\end{array}$ & $\begin{array}{l}31.5 \\
40.0 \\
49.5 \\
40.5 \\
31.5\end{array}$ & $\begin{array}{l}1.5 \\
2.0 \\
2.1 \\
1.9 \\
1.4\end{array}$ & $\begin{array}{l}4.76 \\
5.00 \\
4.24 \\
4.69 \\
4.44\end{array}$ & $\begin{array}{l}128.1 \\
157.5 \\
174.0 \\
150.0 \\
140.5\end{array}$ & $\begin{array}{r}8.4 \\
11.1 \\
12.0 \\
10.5 \\
9.2\end{array}$ & $\begin{array}{l}6.55 \\
7.05 \\
6.90 \\
7.00 \\
6.62\end{array}$ \\
\hline Ave.. & 38.6 & 1.8 & 4.63 & 150.1 & 10.1 & 6.82 \\
\hline
\end{tabular}


IV. (continued)

Flowering Stage

\begin{tabular}{|c|c|c|c|c|c|c|}
\hline \multirow{2}{*}{$\begin{array}{l}\text { Plant } \\
\text { No. }\end{array}$} & \multicolumn{3}{|c|}{ LEAVES } & \multicolumn{3}{|c|}{ STEM } \\
\hline & $\begin{array}{l}\text { Fresh } \\
\text { Weight }\end{array}$ & $\begin{array}{c}\text { Dry } \\
\text { Weight }\end{array}$ & $\begin{array}{l}\text { Percentage } \\
\text { Dry Matter }\end{array}$ & $\begin{array}{l}\text { Fresh } \\
\text { Weight }\end{array}$ & $\begin{array}{c}\text { Dry } \\
\text { Weight }\end{array}$ & $\begin{array}{l}\text { Percentage } \\
\text { Dry Matter }\end{array}$ \\
\hline $\begin{array}{r}I \\
I I \\
I I I \\
I V \\
V\end{array}$ & $\begin{array}{l}334.0 \\
297.0 \\
363.0 \\
270.0 \\
359.0\end{array}$ & $\begin{array}{l}24.5 \\
23.0 \\
29.5 \\
24.0 \\
26.5\end{array}$ & $\begin{array}{l}7.34 \\
7.74 \\
8.13 \\
8.89 \\
7.38\end{array}$ & $\begin{array}{l}86.0 \\
72.0 \\
97.0 \\
82.0 \\
94.0\end{array}$ & $\begin{array}{l}5.5 \\
5.0 \\
6.5 \\
6.0 \\
5.0\end{array}$ & $\begin{array}{l}6.40 \\
6.94 \\
6.70 \\
7.32 \\
5.32\end{array}$ \\
\hline Ave.. & 324.6 & $25 \cdot 5$ & 7.90 & 86.2 & 5.6 & 6.54 \\
\hline \multicolumn{4}{|c|}{ ROOT } & \multicolumn{3}{|c|}{ - WHOLE PLANT } \\
\hline $\begin{array}{r}I \\
I I \\
I I I \\
I V \\
V\end{array}$ & $\begin{array}{r}111.0 \\
103.0 \\
138.0 \\
91.0 \\
112.0\end{array}$ & $\begin{array}{l}5.0 \\
5.0 \\
6.5 \\
5.0 \\
6.0\end{array}$ & $\begin{array}{l}4.50 \\
4.85 \\
4.71 \\
5.49 \\
5.36\end{array}$ & $\begin{array}{l}531.0 \\
472.0 \\
598.0 \\
443.0 \\
565.0\end{array}$ & $\begin{array}{l}35.0 \\
33.0 \\
42.5 \\
35.0 \\
37.5\end{array}$ & $\begin{array}{l}6.59 \\
6.99 \\
7.11 \\
7.90 \\
6.55\end{array}$ \\
\hline Ave.. & 111.0 & 5.5 & 4.98 & 521.8 & 36.6 & 7.00 \\
\hline
\end{tabular}


IV. (coritinued)

Fruit Setiing Stage

\begin{tabular}{|c|c|c|c|c|c|c|}
\hline \multirow{2}{*}{$\begin{array}{l}\text { Plant } \\
\text { No. }\end{array}$} & \multicolumn{3}{|c|}{ LEAVES } & \multicolumn{3}{|c|}{ STEM } \\
\hline & $\begin{array}{l}\text { Fresh } \\
\text { Weight }\end{array}$ & $\begin{array}{c}\text { Dry } \\
\text { Weight }\end{array}$ & $\begin{array}{l}\text { Percentage } \\
\text { Dry Matter }\end{array}$ & $\begin{array}{l}\text { Fresh } \\
\text { Weight }\end{array}$ & \begin{tabular}{|l} 
Dry \\
We1ght
\end{tabular} & $\begin{array}{l}\text { Percentage } \\
\text { Dry Matter }\end{array}$ \\
\hline $\begin{array}{r}I \\
I I \\
I I I \\
I V \\
V\end{array}$ & $\begin{array}{l}817.0 \\
799.0 \\
762.0 \\
847.0 \\
654.0\end{array}$ & $\begin{array}{l}83.2 \\
78.8 \\
72.3 \\
85.6 \\
57.2\end{array}$ & $\begin{array}{r}10.18 \\
9.86 \\
9.48 \\
10.11 \\
8.75\end{array}$ & $\begin{array}{l}264.0 \\
228.0 \\
243.0 \\
236.0 \\
225.0\end{array}$ & $\begin{array}{l}22.4 \\
21.5 \\
22.8 \\
21.5 \\
18.7\end{array}$ & $\begin{array}{l}8.48 \\
9.43 \\
9.38 \\
9.11 \\
8.31\end{array}$ \\
\hline Ave.. & 775.8 & 75.4 & 9.68 & 239.2 & 21.4 & 8.94 \\
\hline \multicolumn{4}{|c|}{ FRUIT } & \multicolumn{3}{|c|}{ ROOT } \\
\hline $\begin{array}{r}I \\
I I \\
I I I \\
I V \\
V\end{array}$ & $\begin{array}{r}26.5 \\
4.7 \\
30.3 \\
11.0 \\
7.7\end{array}$ & $\begin{array}{l}1.9 \\
0.3 \\
2.1 \\
0.9 \\
0.6\end{array}$ & $\begin{array}{l}7.17 \\
7.32 \\
6.93 \\
8.18 \\
7.79\end{array}$ & $\begin{array}{l}231.0 \\
293.0 \\
260.5 \\
280.0 \\
200.0\end{array}$ & $\begin{array}{l}14.1 \\
18.0 \\
14.5 \\
18.6 \\
13.9\end{array}$ & $\begin{array}{l}6.10 \\
6.14 \\
5.58 \\
6.54 \\
6.95\end{array}$ \\
\hline Ave.. & 15.9 & 1.2 & 7.48 & 252.8 & 15.8 & 6.28 \\
\hline \multicolumn{4}{|c|}{ WHOLE PLANT } & & & \\
\hline $\begin{array}{r}I I \\
I I \\
I I I \\
I V \\
V\end{array}$ & $\begin{array}{l}1338.5 \\
1324.1 \\
1295.3 \\
1374.0 \\
1086.7\end{array}$ & $\begin{array}{r}121.6 \\
118.6 \\
111.7 \\
126.6 \\
90.4\end{array}$ & $\begin{array}{l}9.08 \\
8.96 \\
8.62 \\
9.21 \\
8.32\end{array}$ & & & \\
\hline Ave.. & 1283.7 & 113.8 & 8.86 & & & \\
\hline
\end{tabular}


IV. (continued)

Fruit Enlargement Stage

\begin{tabular}{|c|c|c|c|c|c|c|}
\hline \multirow[b]{2}{*}{$\begin{array}{l}\text { Plant } \\
\text { No. }\end{array}$} & \multicolumn{3}{|c|}{ IEAVES } & \multicolumn{3}{|c|}{ STEM } \\
\hline & $\begin{array}{l}\text { Fresh } \\
\text { Weight }\end{array}$ & \begin{tabular}{|c|} 
Dry \\
Welght
\end{tabular} & $\begin{array}{l}\text { Percentage } \\
\text { Dry Matter }\end{array}$ & $\begin{array}{l}\text { Fresh } \\
\text { Weight }\end{array}$ & $\begin{array}{c}\text { Dry } \\
\text { Welght }\end{array}$ & $\begin{array}{l}\text { Percentage } \\
\text { Dry Matter }\end{array}$ \\
\hline $\begin{array}{r}I \\
I I \\
\text { III } \\
I V \\
V\end{array}$ & $\begin{array}{r}1173.0 \\
1223.0 \\
1340.0 \\
891.0 \\
1160.0\end{array}$ & $\begin{array}{l}101.2 \\
122.0 \\
138.0 \\
120.4 \\
100.7\end{array}$ & $\begin{array}{r}8.62 \\
9.98 \\
10.30 \\
13.51 \\
8.68\end{array}$ & $\begin{array}{l}364.0 \\
487.0 \\
424.0 \\
315.0 \\
428.0\end{array}$ & $\begin{array}{l}30.1 \\
43.6 \\
39.6 \\
35.6 \\
42.7\end{array}$ & $\begin{array}{r}8.26 \\
8.95 \\
9.34 \\
11.30 \\
9.98\end{array}$ \\
\hline Ave.. & 1157.4 & 116.5 & 10.22 & 403.0 & 38.3 & 9.57 \\
\hline \multicolumn{4}{|c|}{ FRUIT } & \multicolumn{3}{|c|}{ ROOT } \\
\hline $\begin{array}{r}I \\
I I \\
I I I \\
I V \\
V\end{array}$ & $\begin{array}{r}132.0 \\
613.0 \\
98.0 \\
143.0 \\
244.0\end{array}$ & $\begin{array}{r}7.9 \\
36.2 \\
5.8 \\
10.2 \\
13.9\end{array}$ & $\begin{array}{l}5.98 \\
5.91 \\
5.92 \\
7.13 \\
5.70\end{array}$ & $\begin{array}{l}363.0 \\
270.0 \\
325.0 \\
346.0 \\
252.0\end{array}$ & $\begin{array}{l}20.0 \\
17.6 \\
21.1 \\
24.1 \\
19.9\end{array}$ & $\begin{array}{l}5.51 \\
6.52 \\
6.49 \\
6.96 \\
7.90\end{array}$ \\
\hline Ave.. & 246.0 & 14.8 & 6.13 & 311.2 & 20.5 & 6.68 \\
\hline \multicolumn{4}{|c|}{ WHOLE PLANT } & & & \\
\hline $\begin{array}{r}I \\
I I \\
I I I \\
I V \\
V\end{array}$ & $\begin{array}{l}2032.0 \\
2593.0 \\
2187.0 \\
1695.0 \\
2084.0\end{array}$ & $\begin{array}{l}159.2 \\
219.4 \\
204.5 \\
190.3 \\
177.2\end{array}$ & $\begin{array}{r}7.83 \\
8.46 \\
9.35 \\
11.23 \\
8.50\end{array}$ & & & \\
\hline Ave.. & 2118.2 & 190.1 & 8.98 & & & \\
\hline
\end{tabular}


V. THE STATISTICAL ANALYSES OF THE DATA, IN LOGARITHMS, FOR THE RATE OF ABSORPTION OF

SOME ELEMENTS MADE BY FIVE TOMATO

PLANIS AT DIFFERENT STAGES

OF GROWTH

\section{The Use of Logarithms*}

A randomized block analysis assumes that the error varlance of any observation is the same throughout the plots; if the error varlance for a given observation is proportional to the respective true mean, then, the correct procedure is to analyze the logarithm of the observation.

Since in this particular experiment it was found that the rate of absorption of any of the studied elements decreased considerably in magnitude with the treatments, this indicates that the observations of the first treatments may have larger true means than the observations of the last treatments, and hence, different observations may have different error variances which in turn may be proportional to the respective true means. Therefore, the conversion of the original data into logarithms was imperative in order to have the same error varlance in all the treatments.

* A private communication from Dr. D. B. Duncan to 
VI. COIPUTATIONS FOR THE ANALYSES OF VARIANCE, AND FITTING OF THE POLYNOVIAL REGRESSIONS FOR THE RATE OF ABSORPTION OF POTASSIUN

EXPRESSED ON FRESH, OR DRY WEIGHT BASIS OF THE WHOLE PLANT

\begin{tabular}{|c|c|c|c|c|c|c|}
\hline \multirow[b]{3}{*}{$\begin{array}{l}\text { Repli- } \\
\text { cation }\end{array}$} & \multicolumn{4}{|c|}{$\begin{array}{l}\text { Data for Unit Fresh Weight } \\
\text { (in logarithrns) }\end{array}$} & & \\
\hline & \multicolumn{6}{|c|}{ Treatments } \\
\hline & 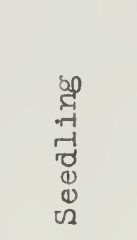 & 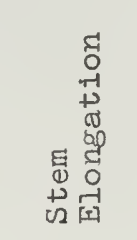 & 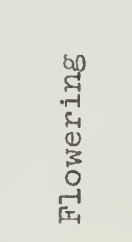 & 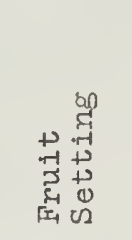 & 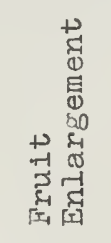 & 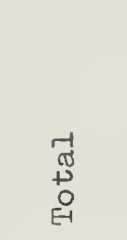 \\
\hline $\begin{array}{l}1 \\
2 \\
3 \\
4 \\
5\end{array}$ & $\begin{array}{l}2.867 \\
2.546 \\
2.523 \\
2.805 \\
2.798\end{array}$ & $\begin{array}{l}2.504 \\
2.502 \\
2.422 \\
2.467 \\
2.515\end{array}$ & $\begin{array}{l}2.321 \\
2.321 \\
2.342 \\
2.314 \\
2.258\end{array}$ & $\begin{array}{l}2.051 \\
2.228 \\
2.147 \\
2.158 \\
2.317\end{array}$ & $\begin{array}{l}1.864 \\
1.768 \\
1.938 \\
1.977 \\
1.911\end{array}$ & $\begin{array}{l}11.607 \\
11.365 \\
11.372 \\
11.721 \\
11.799\end{array}$ \\
\hline Total.. & 13.539 & 12.410 & 11.556 & 10.901 & 9.458 & 57.864 \\
\hline Mean... & 2.708 & 2.482 & 2.311 & 2.180 & 1.892 & 2.315 \\
\hline
\end{tabular}

COMPUTING THE SUM OF SQUARES

Correction Factor: $\quad C=\frac{G^{2}}{N}=\frac{57.864^{2}}{25}=133.930$

Total: $\sum y_{i j}^{2}-C=136.006-133.930=2.076$

Treatments: $\sum \frac{T_{i}^{2}}{r}-c=135.828-133.930=1.898$

Replications: $\sum \frac{R_{j}^{2}}{t}-c=133.961-133.930=0.031$

Error: (total s.s.)-(treatments s.s.)-(replications s.s.) =

$$
2.076-1.929=0.147
$$


VI. (continued)

Contribution of the Linear Regression to the s.s. $z_{1}=(-2)(13.539)+(-1)(12.410)+0(11.556)+1(10.901) \ldots$ $\ldots+2(9.458)=-9.671$

s.s. $z_{1}=\frac{z_{1}^{2}}{D_{1}}=\frac{-9.671^{2}}{5 \times 10}=\frac{93.528}{50}=1.871$

Contribution of the Quadratic Regression to the s.s. $z_{2}=2(13.539)+(-1)(12.410)+(-2)(11.556)+(-1)(10.901)$ $\cdots+2(9.458)=-0.429$

s.s. $z_{2}=\frac{z_{2}^{2}}{D_{2}}=\frac{-0.429^{2}}{5 \times 14}=\frac{0.184}{70}=0.003$ Regression Coefficient: $b_{1}=\frac{z_{1}}{D_{1}}=\frac{-9.671}{50}=-0.193$ General Mean: $\bar{y}=\frac{G}{N}=\frac{57.864}{25}=2.315$ Computing $\hat{y}_{i}: \hat{y}=\bar{y}+b_{1} \bar{\xi}^{\prime}$

$$
\begin{array}{ll}
\widehat{y}_{1}= & 2.315+(-2)(-0.193)=2.701 \\
\widehat{y}_{2} & 2.701-0.193=2.508 \\
\widehat{y}_{3} & 2.508-0.193=2.315 \\
\widehat{y}_{4}= & 2.315-0.193=2.122 \\
\widehat{y}_{5}= & 2.315+2(-0.193)=1.929
\end{array}
$$


VI. (continued)

\begin{tabular}{l|r|r|r|r|r|r}
\hline \hline \multicolumn{7}{c}{ Data for Unit Dry Weight } \\
(1n logarithms)
\end{tabular}

COMPUTING THE SUM OF SQUARES

Correction Factor: $\quad c=\frac{\mathrm{G}^{2}}{\mathrm{~N}}=\frac{85.900^{2}}{25}=295.152$

Total: $\sum \mathrm{y}_{i j}^{2}-\mathrm{C}=298.092-295.152=2.940$

Treatments: $\sum \frac{T_{i}^{2}}{r}-c=297.887-295.152=2.735$

Replications: $\sum \frac{R^{2}}{t}-C=295.204-295.152=0.052$

Error: (total s.s.)-(treatments s.s.)-(replications s.s.) =

$$
2.941-2.787=0.153
$$


VI. (continued)

Contribution of the Linear Regression to the s.s. $z_{1}=(-2)(19.480)+(-1)(18.243)+0(17.321)+1(16.169) \ldots$

$\ldots+2(14.687)=-11.660$
s.s. $z_{1}=\frac{z_{1}^{2}}{D_{1}}=\frac{-11.660^{2}}{5 \times 10}=\frac{135.96}{50}=2.719$

Contribution of the Quadratic Regression to the s.s. $z_{2}=2(19.480)+(-1)(18.243)+(-2)(17.321)+(-1)(16.169)$

$\quad \cdots+2(14.687)=-0.720$
s.s. $z_{2}={\frac{z_{2}}{D_{2}}}^{2}=\frac{-0.720^{2}}{5 \times 14}=\frac{0.518}{70}=0.007$ Regression Coefficient: $b_{1}=\frac{z_{1}}{D_{1}}=\frac{-11.660}{50}=-0.233$ General Mean: $\bar{y}=\frac{G}{N}=\frac{85.900}{25}=3.436$ Computing $\hat{y}_{i}: \hat{y}=\bar{y}+b_{1} \xi_{i}^{\prime}$

$$
\begin{array}{ll}
\widehat{\mathrm{y}_{1}}= & 3.436+(-2)(-0.233)=3.902 \\
\widehat{\mathrm{y}}_{2}= & 3.902-0.233=3.669 \\
\widehat{\mathrm{y}}_{3}= & 3.669-0.233=3.436 \\
\widehat{\mathrm{y}}_{4}= & 3.436-0.233=3.203 \\
\widehat{\mathrm{y}}_{5}= & 3.436+2(-0.233)=2.970
\end{array}
$$


VII. CONPUTATIONS FOR THE ANALYSES OF VARIANCE, AND FITTING OF THE POLYNOMIAL REGRESSIONS FOR

THE RATE OF ABSORPTION OF CALCIUM

EXPRESSED ON FRESH, OR DRY

WEIGHT BASIS OF THE WHOLE PIANT

Data for Unit Fresh Weight

(in logarithms)

\begin{tabular}{|c|c|c|c|c|c|c|}
\hline \multirow[b]{2}{*}{$\begin{array}{l}\text { Repli- } \\
\text { cation }\end{array}$} & \multicolumn{6}{|c|}{ Treatments } \\
\hline & 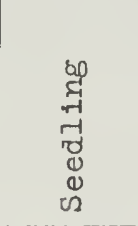 & 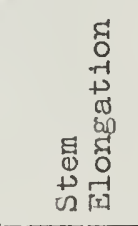 &  & 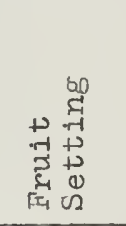 & 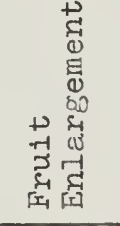 & . \\
\hline $\begin{array}{l}1 \\
2 \\
3 \\
4 \\
5\end{array}$ & $\begin{array}{l}2.243 \\
2.671 \\
2.450 \\
2.142 \\
2.571\end{array}$ & $\begin{array}{l}2.192 \\
2.104 \\
2.060 \\
2.125 \\
2.153\end{array}$ & $\begin{array}{l}1.780 \\
1.969 \\
2.126 \\
1.997 \\
1.964\end{array}$ & $\begin{array}{l}1.731 \\
1.802 \\
1.803 \\
1.719 \\
1.741\end{array}$ & $\begin{array}{l}1.525 \\
1.490 \\
1.781 \\
1.695 \\
1.644\end{array}$ & $\begin{array}{r}9.471 \\
10.036 \\
10.220 \\
9.678 \\
10.073\end{array}$ \\
\hline Total.. & 12.077 & 10.634 & 9.836 & 8.796 & 8.135 & 49.478 \\
\hline Mean... & 2.415 & 2.127 & 1.967 & 1.759 & 1.627 & 1.979 \\
\hline
\end{tabular}

COIPUTING THE SUM OF SQUARES

Correction Factor: $\quad C=\frac{G^{2}}{N}=\frac{49.478^{2}}{25}=97.923$

Total: $\sum y_{i j}^{2}-C=100.177-97.923=2.254$

Treatments: $\sum \frac{\mathrm{T}^{2} i}{\mathrm{r}}-\mathrm{C}=99.846-97.923=1.923$

Replications: $\sum \frac{R^{2}}{t}-C=98.000-97.923=0.077$

Error: (total s.s.)-(treatments s.s.)-(replications s.s.) = $2.254-2.000=0.254$ 
VII. (continued)

Contribution of the Linear Regression to the s.s. $z_{1}=(-2)(12.077)+(-1)(10.634)+0(9.836)+1(8.796)+\ldots$

$\cdots+2(8.135)=-9.722$
s.s. $z_{I}=\frac{z_{I}^{2}}{D_{I}}=\frac{-9.722^{2}}{5 \times 10}=\frac{24.52}{50}=1.890$

Contribution of the Quadratic Regression to the s.s. $z_{2}=2(12.077)+(-1)(10.634)+(-2)(9.836)+(-1)(8.796)+$

$$
\cdots+2(8.135)=1.322
$$

s.s. $z_{2}=\frac{z_{2}^{2}}{D_{2}}=\frac{1.322^{2}}{5 \times 14}=\frac{1.748}{70}=0.025$

Regression Coefficient: $b_{1}=\frac{z_{1}}{D_{1}}=\frac{-9.722}{50}=-0.194$

General Mean: $\bar{y}=\frac{G}{N}=\frac{49.478}{25}=1.979$

Computing $\widehat{y_{i}}: \hat{y}=\bar{y}+b_{I} \xi_{1}^{\prime}$

$$
\begin{aligned}
& \hat{y}_{1}=1.971+(-2)(-0.194)=2.367 \\
& \widehat{y}_{2}=2.367-0.194=2.173 \\
& \widehat{y}_{3}=2.173-0.194=1.979 \\
& \widehat{y}_{4}=1.979-0.194=1.785 \\
& \widehat{y}_{5}=1.979+2(-0.194)=1.591
\end{aligned}
$$


VII. (continued)

\section{Data for Unit Dry Weight \\ (in logarithms)}

\begin{tabular}{|c|c|c|c|c|c|c|}
\hline \multirow[b]{2}{*}{$\begin{array}{l}\text { Repli- } \\
\text { cation }\end{array}$} & \multicolumn{6}{|c|}{ Treatments } \\
\hline & 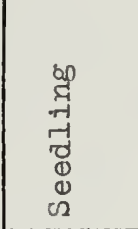 & 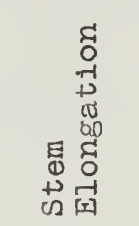 & 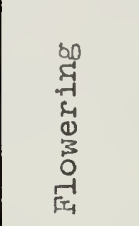 & 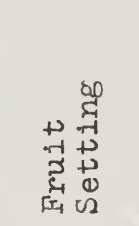 & 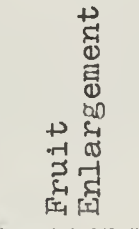 & 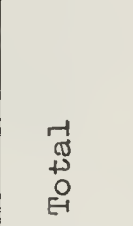 \\
\hline $\begin{array}{l}1 \\
2 \\
3 \\
4 \\
5\end{array}$ & $\begin{array}{l}3.456 \\
3.872 \\
3.602 \\
3.284 \\
3.806\end{array}$ & $\begin{array}{l}3.377 \\
3.256 \\
3.222 \\
3.280 \\
3.331\end{array}$ & $\begin{array}{l}2.961 \\
3.125 \\
3.275 \\
3.099 \\
3.142\end{array}$ & $\begin{array}{l}2.772 \\
2.850 \\
2.868 \\
2.755 \\
2.822\end{array}$ & $\begin{array}{l}2.631 \\
2.562 \\
2.810 \\
2.645 \\
2.715\end{array}$ & $\begin{array}{l}15.197 \\
15.665 \\
15.777 \\
15.063 \\
15.816\end{array}$ \\
\hline Total.. & 18.020 & 16.466 & 15.602 & 14.067 & 13.363 & 77.518 \\
\hline Mean... & 3.604 & 3.293 & 3.120 & 2.813 & 2.673 & 3.101 \\
\hline
\end{tabular}

COPPUTING THE SUM OF SQUARES

Correction Factor: $\quad C=\frac{G}{N}^{2}=\frac{77.518^{2}}{25}=240.362$

Total: $\sum y_{i j}^{2}-c=243.492-240.362=3.130$

Treatments: $\sum \frac{T_{i}^{2}}{r}-C=243.144-240.362=2.782$

Replications: $\sum \frac{R_{j}^{2}}{t}-C=240.459-240.362=0.097$

Error: (total s.s.)-(treatments s.s.)-(replications s.s.) =

$$
3.140-2.888=0.251
$$


VII. (continued)

Contribution of the Linear Regression to the s.s. $z_{1}=(-2)(18.020)+(-1)(16.466)+0(15.602+1(14.067+\ldots$

s.s. $z_{1}=\frac{z_{1}^{2}}{D_{1}}=\frac{-11.213^{2}}{5 \times 10}=\frac{137.194}{50}=2.744$

Contribution of the Guadratic Regression to the s.s. $z_{2}=2(18.020)+(-1)(16.466)+(-2)(15.602)+(-1)(14.067)$$$
\cdots+2(13.363)=1.029
$$

s.s. $z_{2}=\frac{z_{2}{ }^{2}}{D_{2}}=\frac{1.029^{2}}{5 \times 14}=\frac{1.059}{70}=0.015$

Regression Coefficient: $b_{1}=\frac{z_{1}}{D_{1}}=\frac{-11.713}{50}=-0.234$ General Mean: $\bar{y}=\frac{G}{N}=\frac{27.518}{25}=3.101$ Computing $\hat{y}_{i}: \hat{y}=\bar{y}+b_{1} \xi_{1}^{\prime}$

$$
\begin{array}{ll}
\hat{y}_{1}= & 3.101+(-2)(-0.234)=3.569 \\
\hat{y}_{2} & 3.569-0.234=3.335 \\
\hat{y}_{3} & 3.335-0.234=3.101 \\
\hat{y}_{4}=3.101-0.234=2.867 \\
\hat{y}_{5}=3.101+2(-0.234)=2.633
\end{array}
$$


VIII. TEST OF THE SIGNIFICANCE OF THE DIFFERENCE BETWEEN ANY TWO CONSECUTIVE POINTS

IN A QUADRATIC OR CUBIC REGRESSION

The ratio of the difference $\left(\alpha=\hat{y}_{i}-\hat{y}_{j}\right)$ between any two consecutive points $\left(\hat{y}_{i}\right.$ and $\hat{y}_{j}$, which are the best estimates of the treatment means as given by the polynomial regressions) and 1ts standard error follows the Student's $t$ aistribution.

$$
t_{\mathrm{d}}=\frac{\mathrm{d}}{\mathrm{s}_{\mathrm{d}}}
$$

where $s_{d}$ is the standard error of the difference. To obtain the standard error of the difference, first calculate the variance of the difference according to the following formula:

$$
s_{d}^{2}=\left[\frac{\left(\xi_{1 i}^{\prime}-\xi_{1, j}\right)^{2}}{D_{1}}-\frac{\left(\xi_{2 i}^{\prime}-\xi_{2 j}\right)^{2}}{D_{2}}\right] s_{e}^{2}
$$

where $\xi_{1 i}=-2 ; \xi_{1 j}^{\prime}=-1 ; \xi_{2 i}^{\prime}=-1 ;$ and $\xi_{2 j}^{\prime}=-2$ are the appoprlate ortinogonal polynomial coefficients according to Fisher and Yates (26); and $D_{1}$ and $D_{2}$ are the corresponding divisors. The error variance $\left(s_{e}^{2}\right)$ is obtained from the analysis of variance.

Finally, $s_{d}=\sqrt{s_{d}^{2}}$. For each of the differences compute the respective standard error.

When the cubic effect is significant the formula for the variance of the difference is:

$$
s_{d}^{2}=\left[\frac{\left(\xi_{1 i}^{\prime}-\xi_{1, j}^{\prime}\right)^{2}}{D_{1}}+\frac{\left(\xi_{2 i}^{\prime}-\xi_{2 i}\right)^{2}}{D_{2}}+\frac{\left(\xi_{3 i}^{\prime}-\xi_{3 j}\right)^{2}}{D_{3}}\right] s_{e}^{2}
$$


VIII. (continued)

$$
\text { where } \xi_{3 i}^{\prime}=-1 \text {; and } \xi_{3 j}^{\prime}=2 \text { are the additional }
$$

orthogonal polynomials coefficients; and $D_{3}$ is the additional divisor.

The computed " $t$ " value for each difference is then compared with the values for "t" given by the table with " $n$ " degrees of freedom ( $n=d$. f. for error), and the chosen level of significance. 
IX. COMPUTATIONS FOR THE ANALYSES OF VARIANCE, AND FITTING OF THE POLYNOMIAL REGRESSIONS FOR THE RATE OF ABSORPTION OF MAGNESIUM EXPRESSED ON FRESH, OR DRY WEIGHT BASIS OF THE WHOLE PLANT

\begin{tabular}{l|c|c|c|c|c|c}
\multicolumn{7}{c}{ Data for Unit Fresh We1ght } \\
(1n logarithms)
\end{tabular}

CONPUTING THE SUM OF SQUARES

Correction Factor: $\quad C=\frac{G^{2}}{N}=\frac{27.010^{2}}{25}=29.182$ Total: $\sum y_{i j}^{2}-C=32.669-29.182=3.487$ Treatments: $\sum \frac{T^{2}}{r}-C=31.420-29.182=2.238$ Replications: $\sum \frac{R_{i}^{2}}{t}-C=29.255-29.182=0.073$ Error: (total s.s.)-(treatments s.s.)-(replications s.s.) = $3.487-2.311=1.176$ 
IX. (continued)

Contribution of the Inear Regression to the s.s.

$$
\begin{gathered}
z_{1}=(-2)(6.253)+(-1)(6.856)+0(6.239)+1(4.997) \\
\ldots+2(2.665)=-9.045 \\
\text { s.s. } z_{1}=\frac{z_{1}^{2}}{D_{1}}=\frac{-9.045^{2}}{5 \times 10}=\frac{81.812}{50}=1.636
\end{gathered}
$$

Contribution of the Quadratic Regression to the s.s.

$$
\begin{gathered}
z_{2}=2(6.253)+(-1)(6.856)+(-2)(6.239)+(-1)(4.997)+\ldots \\
\ldots+2(2.665)=-6.485 \\
\text { s.s. } z_{2}=\frac{z_{2}^{2}}{D_{2}}=\frac{-6.485^{2}}{5 \times 14}=\frac{42.055}{70}=0.601
\end{gathered}
$$

Regression Coefficients: $b_{1}=\frac{z_{I}}{D_{1}}=\frac{-9.045}{50}=-0.181$

$$
b_{2}=\frac{z_{2}}{D_{2}}=\frac{-6.485}{70}=-0.093
$$

General Mean: $\bar{y}=\frac{G}{N}=\frac{27.010}{25}=1.080$

Computing $\hat{\mathrm{y}}_{i}: \hat{\mathrm{y}}=\overline{\mathrm{y}}+\mathrm{b}_{1} \bar{\xi}_{1}^{\prime}+\mathrm{b}_{2} \bar{\xi}_{2} \quad\left(\mathrm{~b}_{2}\right.$ is included because the quadratic effect is significant)

$$
\begin{aligned}
& \hat{y}_{1}=1.080+(-2)(-.181)+2(-.093)=1.256 \\
& \hat{y}_{2}=1.080+(-1)(-.181)+(-1)(-.093)=1.354 \\
& \hat{y}_{3}=1.080+0(-.181)+(-2)(-.093)=1.266 \\
& \hat{y}_{4}=1.080+1(-.181)+(-1)(-.093)=0.992 \\
& \widehat{y}_{5}=1.080+2(-.181)+2(-.093)=0.532
\end{aligned}
$$


IX. (continued)

\begin{tabular}{|c|c|c|c|c|c|c|}
\hline \multicolumn{7}{|c|}{$\begin{array}{l}\text { Data for Unit Dry Weight } \\
\text { (in logarithms) }\end{array}$} \\
\hline \multirow[b]{2}{*}{$\begin{array}{l}\text { Repli- } \\
\text { cation }\end{array}$} & \multicolumn{6}{|c|}{ Treatments } \\
\hline & 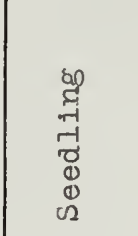 & 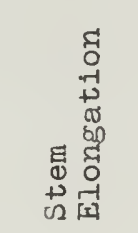 & 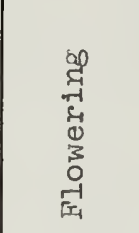 & 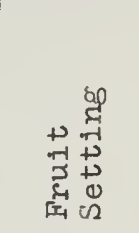 & 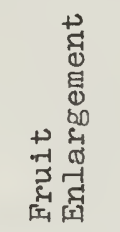 & 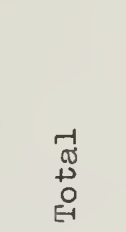 \\
\hline $\begin{array}{l}1 \\
2 \\
3 \\
4 \\
5\end{array}$ & $\begin{array}{l}2.927 \\
1.968 \\
2.524 \\
2.789 \\
1.982\end{array}$ & $\begin{array}{l}2.695 \\
2.349 \\
2.616 \\
2.450 \\
2.578\end{array}$ & $\begin{array}{l}2.412 \\
2.502 \\
2.350 \\
2.234 \\
2.511\end{array}$ & $\begin{array}{l}1.687 \\
2.044 \\
2.195 \\
1.988 \\
2.354\end{array}$ & $\begin{array}{l}1.620 \\
1.741 \\
1.626 \\
1.285 \\
1.599\end{array}$ & $\begin{array}{l}11.341 \\
10.604 \\
11.311 \\
10.746 \\
11.024\end{array}$ \\
\hline Total.. & 12.190 & 12.688 & 12.009 & 10.268 & 7.871 & 55.026 \\
\hline Mean... & 2.438 & 2.538 & 2.402 & 2.054 & 1.574 & 2.201 \\
\hline
\end{tabular}

COMPUTING THE SUM OF SQUARES

Correction Factor: $\quad C=\frac{G^{2}}{N}=\frac{55.026^{2}}{25}=121.114$

Total: $\sum y_{i j}^{2}-c=125.530-121.114=4.416$

Treatments: $\sum \frac{T_{i}^{2}}{r}-c=124.236-121.114=3.122$

Repilcations: $\sum \frac{R_{j}^{2}}{t}-C=121.201-121.114=0.087$

Error: (total s.s.)-(treatments s.s.)-(replications s.s.) =

$$
4.468-3.241=1.207
$$


IX. (continued)

Contribution of the Linear Regression to the s.s.

$z_{1}=(-2)(12.190)+(-1)(12.688)+0(12.009)+1(10.268)+\ldots$ $\ldots+2(7.871)=-11.058$

s.s. $z_{1}=\frac{z_{1}^{2}}{D_{1}}=\frac{-11.058^{2}}{5 \times 10}=\frac{122.279}{50}=2.446$

Contribution of the quadratic regression to the s.s. $z_{2}=2(12.190)+(-1)(12.688)+(-2)(12.009)+(-1)(10.268)$

$$
\ldots+2(7.871)=-6.852
$$

s.s. $z_{2}=\frac{z_{2}^{2}}{D_{2}}=\frac{-6.852^{2}}{5 \times 14}=\frac{46.950}{70}=0.671$

Regression Coefficients: $b_{1}=\frac{z_{1}}{D_{1}}=\frac{11.058}{50}=-0.221$

$$
b_{2}=\frac{z_{2}}{D_{2}}=\frac{-6.852}{60}=-0.098
$$

General Mean: $\overline{\mathrm{y}}=\frac{G}{\mathrm{~N}}=\frac{55.026}{25}=2.201$

Computing $\widehat{y}_{i}: \hat{y}=\bar{y}+b_{1} \xi_{1}^{\prime}+b_{2} \bar{\xi}_{2}^{\prime}$

$$
\begin{aligned}
& \widehat{y}_{1}=2.201+(-2)(-.221)+2(-.098)=2.447 \\
& \widehat{y}_{2}=2.201+(-1)(-.221)+(-1)(-.098)=2.520 \\
& \widehat{y}_{3}=2.201+0(-.221)+(-2)(-.098)=2.397 \\
& \widehat{y}_{4}=2.201+1(-.221)+(-1)(-.098)=2.078 \\
& \hat{y}_{5}=2.201+2(-.221)+2(-.098)=1.563
\end{aligned}
$$


X. COIPUTATIONS FOR THE ANALYSES OF VARIANCE, AND FITTING OF THE POLYNOMIAL REGRESSIONS FOR THE RATE OF ABSORPTION OF PHOSPHORUS EXPRESSED ON FRESH, OR DRY WEIGHT BASIS OF THE WHOLE PIANT

\begin{tabular}{l|r|r|r|r|r|r}
\hline \multicolumn{7}{c}{ Data for Unit Fresh Weight } \\
(in logarithms)
\end{tabular}

COMPUTING THE SUM OF SQUARES

Correction Factor: $\quad c=\frac{C^{2}}{N}=\frac{37.306^{2}}{25}=55.669$

Total: $\sum y_{i j}^{2}-c=57.460-55.669=1.791$

Treatments: $\Sigma \frac{T_{i}^{2}}{r}-C=57.293-55.669=1.624$

Replications: $\sum \frac{R_{j}^{2}}{t}-C=55.675-55.669=0.006$

Error: (total s.s.)-(treatments s.s.)-(replications s.s.) =

$$
1.791-1.630=0.161
$$


X. (continued)

Contribution of the Linear Regression to the s.s.

$$
\begin{gathered}
z_{I}=(-2)(9.364)+(-1)(7.749)+0(7.784)+1(6.964) \\
\ldots+2(5.445)=-8.623 \\
\text { s.s. } z_{I}=\frac{z_{I}^{2}}{D_{I}}=\frac{-8.623^{2}}{5 \times 10}=\frac{74.356}{50}=1.487
\end{gathered}
$$

Contribution of the Guadratic Regression to the s.s.

$$
\begin{gathered}
z_{2}=2(9.364)+(-1)(7.749)+(-2)(7.784)+(-1)(6.964)+\ldots \\
\ldots+2(5.445)=-0.663 \\
\text { s.s. } z_{2}=\frac{z_{2}^{2}}{D_{2}}=\frac{-0.663^{2}}{5 \times 14}=\frac{0.440}{70}=0.006
\end{gathered}
$$

Contribution of the Cubic Regression to the s.s.

$$
\begin{gathered}
z_{3}=-1(9.364)+2(7.749)+0(7.784)+(-2)(6.964)+\ldots \ldots \\
\ldots+1(5.445)=-2.349 \\
\text { s.s. } z_{3}=\frac{z_{3}^{2}}{D_{3}}=\frac{-2.349^{2}}{5 \times 10}=\frac{5.518}{50}=0.110
\end{gathered}
$$

Regression Coefficients: $b_{1}=\frac{z_{1}}{D_{1}}=\frac{-8.623}{50}=-0.172$

$$
\begin{aligned}
& b_{2}=\frac{z_{2}}{D_{2}}=\frac{-0.663}{70}=-0.009 \\
& b_{3}=\frac{z_{3}}{D_{3}}=\frac{-2.349}{50}=-0.047
\end{aligned}
$$

General Mean: $\bar{y}=\frac{G}{N}=\frac{32.306}{25}=1.492$ 
X. (continued)

Computing $\widehat{y}_{i}: \widehat{y}=\bar{y}+b_{1} \xi_{1}^{\prime}+b_{2} \xi_{2}^{\prime}+b_{3} \xi_{3}^{\prime} \quad$ ( $b_{3}$ is included because the cubic effect is significant)

$$
\hat{\mathrm{y}}_{1}=1.492+(-2)(-.172)+2(-.009)+\ldots \ldots
$$$$
\cdots+(-1)(-.947)=1.865
$$$$
\widehat{y}_{2}=1.492+(-1)(-.172)+(-1)(-.009)+\ldots
$$$$
\ldots+2(-.047)=1.579
$$$$
\widehat{\mathrm{y}}_{3}=1.492+0(-.172)+(-2)(-.009)+\ldots \ldots
$$$$
\ldots+0(-.047)=1.510
$$$$
\hat{y}_{4}=1.492+1(-.172)+(-1)(-.009)+\ldots \ldots
$$$$
\ldots+(-2)(-.047)=1.423
$$$$
\widehat{y}_{5}=1.492+2(-.172)+2(-.009)+\ldots \ldots \ldots
$$$$
\ldots+I(-.047)=1.083
$$ 
X. (continued)

\begin{tabular}{l|r|r|r|r|r}
\hline \hline \multicolumn{7}{c}{ Data for Unit Dry weight } \\
(1n logarithms)
\end{tabular}

COIPUTING THE SUM OF SQUARES

Correction Factor: $\quad C=\frac{G^{2}}{N}=\frac{65.346^{2}}{25}=170.804$

Total: $\sum y_{i j}^{2}-c=173.421-170.804-2.617$

Treatments: $\sum \frac{T_{i}^{2}}{r}-c=173.185-170.804=2.381$

Replications: $\Sigma \frac{R_{j}^{2}}{t}-C=170.837-170.804=0.033$

Error: (total s.s.)-(treatments s.s.)-(replications s.s.) =

$$
2.617-2.414=0.203
$$


X. (continued)

Contribution of the Linear Regression to the s.s.

$$
\begin{gathered}
z_{1}=(-2)(15.304)+(-1)(13.582)+0(13.549)+1(12.233)+\ldots \\
\ldots+2(10.678)=-10.601
\end{gathered}
$$

s.s. $z_{1}=\frac{z_{1}^{2}}{D_{1}}=\frac{-10.601}{5 \times 10}=\frac{112.381}{50}=2.248$

Contrioution of the Quadratic Regression to the s.s.

$$
\begin{array}{r}
z_{2}=2(15.304)+(-1)(13.582)+(-2)(13.549)+\ldots \ldots \ldots \\
\ldots+(-1)(12.233)+2(10.678)=-0.949
\end{array}
$$

s.s. $z_{2}=\frac{z_{2}^{2}}{D_{2}}=\frac{-0.949^{2}}{70}=\frac{0.901}{70}=0.013$

Contribution of the Cubic Regression to the s.s. $z_{3}=-1(15.304)+2(13.582)+0(13.549)+(-2)(12.233)+\ldots$

$$
\ldots+1(10.678)=-1.928
$$

s.s. $z_{3}=\frac{z_{3}^{2}}{D_{3}}=\frac{-1.928^{2}}{5 \times 10}=\frac{3.717}{50}=0.074$

Regression Coefficients: $b_{1}=\frac{z_{1}}{D_{1}}=\frac{-10.601}{50}=-0.212$

$$
\begin{aligned}
& b_{2}=\frac{z_{2}}{D_{2}}=\frac{-0.949}{70}=-0.014 \\
& b_{3}=\frac{z_{3}}{D_{3}}=\frac{-1.928}{50}=-0.039
\end{aligned}
$$

General Mean: $\bar{y}=\frac{G}{N}=\frac{65.346}{25}=2.614$ 
78

X. (continued)

Computing $\hat{\mathrm{y}}_{i}: \hat{\mathrm{y}}=\mathrm{y}+\mathrm{b}_{1} \xi_{1}^{\prime}+\mathrm{b}_{2} \xi_{2}^{\prime}+\mathrm{b}_{3} \xi_{3}^{\prime}$

$$
\begin{aligned}
\hat{y}_{1}= & 2.614+(-2)(-.212)+2(-.014)+\ldots \ldots \ldots \\
& \ldots+(-1)(-.039)=3.049 \\
\hat{y}_{2}= & 2.614+(-1)(-.212)+(-1)(-.014)+\ldots \ldots \\
& \ldots+2(-.039)=2.762 \\
\hat{y}_{3}= & 2.614+0(-.212)+(-2)(-.014)+\ldots \ldots \ldots \\
& \ldots+0(-.039)=2.642 \\
\hat{y}_{4}= & 2.614+1(-.212)+(-1)(-.014)+\ldots \ldots \ldots \\
& \ldots+(-2)(-.039)=2.494 \\
\hat{y}_{5}= & 2.614+2(-.212)+2(-.014)+\ldots \ldots \ldots \\
& \ldots+1(-.039)=2.123
\end{aligned}
$$




\section{BIBLIOGRAPHY}

1. Bonner, J., and Galston, A. W. Principles of Plant Physiology. Freeman and Company. Pp. 47 and 48. 1952 .

2. Miller, E. C. Plant Pnysiology. McGraw-Hill Book Company, Inc. Pp. 369, 231 and 371. 1938.

3. Burā, J. S. Rate of absorption of soil constituents at successive stages of plant growth. Jour. Agr. Res. 18: 51-72. 1919.

4. MacGillivray, J. H. Effect of phosphorus on the composition of the tornato plant. Jour. Agr. Res. 34: 97-127. 1927.

5. Arnon, D. I., et al. Radioactive phosohorus as an indicator of phosphorus absorption of tomato fruits at various stages of development. Am. Jour. Bot. 27: 791-98. 1940.

6. Steward, F. C. Mineral Nutrition of Plants. Am. Rev. Biochemistry. 4: 519-544. 1935.

7. Hoagland, D. R. Inorganic Plant Nutrition, Prather Lectures. Pp. 50 and 61. 1948.

8. Hester, J. B., et al. The absorption of nutrients by the tomato plant at different stages of growth. Proc. Am. Soc. Hort. Sc1. 36:720-2. 1939.

9. Collander, R. Selective absorption of cations by higher plants. Plant Phys. 16: 691-720. 1941.

10. McCall, A. G., and Richards, P. E. Mineral food requirements of the wheat plant at different stages of its development. Jour. Am. Soc. Agron. 10: 127-34. 1914.

11. Shive, J. W., and Martin, W. H. A comparative study of salt requirements for young and for mature buckwheat plants in solution cultures. Jour. Agr. Res. 14: 151-176. 1918.

12. Jones, W. J., and Huston, H. A. Composition of maize at various stages of its growth. Ind. Sta. Bul1. 125. 1914. 
13. Pember, F. R. Studies by means of both pot and solution culture of the phosphorus and potasslum requirements of the barley plant during its different periods of growth. R. I. Sta. Bull. 169. 1917 .

14. and McLean, F. T. Econonical use of nitrogen, phosphorus and potassium by barley, oats, and wheat in solution cultures. R. I. Sta. Bull. 199. 1925.

15. Gericke, W. F. The beneficial effect to wheat growth due to depletion of available phosphorus in the cultural media. Science 60: 297-98. 1924.

16. Brenchley, W. E. The phosphate requirement of barley at different periods of growth. Ann. Bot. 43: 89-110. 1929.

17. Gile, P. L., and Carrero, J. O. Ash composition of upland rice at various stages of growth. Jour. Agr. Res. 5: 357-64. 1915.

18. Bartholomew, R. P., and Janssen, G. Luxury consumption of potassium by plants and its significance. Jour. Am. Soc. Agr. 21: 751-65. 1929.

19. Overstreet, R., et al. The effect of calcium on the absorption of potassium by barley roots. Plant Phys. 22: 583-90. 1952.

20. Fisher, P. L. Responses of the tomato in solution cultures with deficiencies and excesses of certain essential elements. Ma. Sta. Bull. 375. 1935 .

21. Hayward, H. E. The Structure of Economic Plants. Mcililan Company. Page 565. 1938.

22. Methods of Analysis used in the Total Quantitative Determinations of the Mineral Elements in Tung Leaves at the U.S.D.A. Fleld Laboratory for Tung Investigations, Gainesville, Florida. (Private communication)

23. Drosdoff, et al. Quantitative licrodetermination of Magnesium in Plant Tissue and Soll Extracts, Anal. Chem. 20: 673-4. 1948. 
24. Snell and Snell. Page 503. Truog and Meyer, Indus. and Eng. Chem. Anal. Ed. 1: 136-39. 1929.

25. Curtis, O. F., and Clark, D. G. Princioles of Plant Physiology. McGraw-Hill Book Company, Inc. 1950 .

26. Fisher, R. A., and Yates, F. Statistical tables for biological, agricultural and medical research. Oliver and Boyd, Edinburg, 3rd ed., 1948. 


\section{BIOGRAPHY}

Eduardo Jimenez Saenz was born in Guadalupe, San Jose, Costa Rica, the 13th of July, 1929.

He completed his High School studies in 1946 in San Jose.

In 1947 he entered the Panamerican School of Agriculture in Honduras; in 1950 he satisfactorily fulfilled the requirements and obtained a Diploma, and went back to Costa Rica where he spent two years working for the Ministry of Agriculture.

In 1952 he was granted with a scholarship by the Panamerican School of Agriculture and entered the University of Florida that same year after having completed a short training course with The Rockefeller Foundation in Mexico. It was in 1954 when he obtained his B. S. degree in Agriculture.

He has pursued his graduate work at the University of Florida, and expects to receive his degree of Master of Science in Agriculture in June, 1955.

He was nominated as a member of the Honorary Fraternities Alpha Zeta and Phi Kappa PhI in 1954, and Gamma Sigma Delta in 1955. 
This thesis was prepared under the direction of the chairman of the candidate's supervisory committee and has been approved by all members of the committee. It was submitted to the Dean of the College of Agriculture and to the Graduate Council and was approved as partial fulfillment of the requirements for the degree of Master of Science.

Date
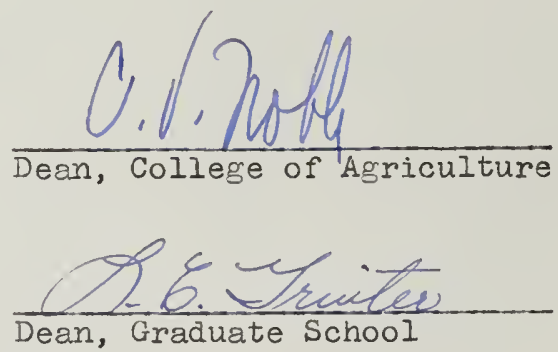

SUPERVISORY COMMITTEE:

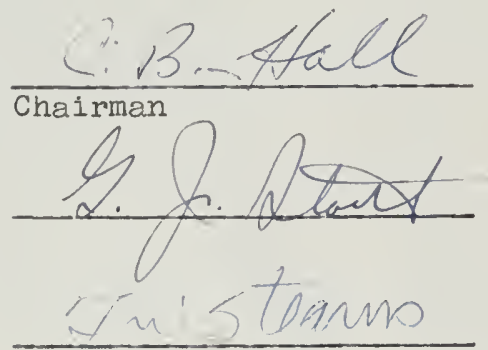

